\title{
Pulmonary Function in the Sick Newborn Infant
}

\author{
ELLEN M. MCCANN, STEVEN L. GOLDMAN, AND JUNE P. BRADY
}

Departments of Pediatrics, Children's Hospital of San Francisco and the University of California, San Francisco and the Cardiovascular Research Institute, University of California, San Francisco, California

Measurement of pulmonary function in the sick infant provides important clinical information and is an important tool for scientific investigation. Herein we review the techniques and limitations of pulmonary function measurements in small, sick newborn infants. Reference values for some of these measurements are provided in Table 1. Many techniques entail some risk and it is vital that the baby's care not be compromised. We perform studies at the bedside with at least two investigators and observe and monitor the baby continuously. We occasionally use chloral hydrate sedation in irritable babies who could not otherwise be studied. However, the value of natural sedation should not be overlooked. As Nicholas Nelson wrote in 1966 (1):“These 'untrained' subjects have proved to be immensely cooperative in the careful hands of patient investigators cognizant of the anesthetic powers of a full stomach."

\section{SKIN SURFACE GAS TENSION AND OXYGEN SATURATION}

Definition. The tensions of $\mathrm{O}_{2}$ and $\mathrm{CO}_{2}$ measured at the skin surface (transcutaneous) and oxygen saturation measured with an ear oximeter or pulse oximeter estimate the arterial values.

Background. Skin surface $\mathrm{PO}_{2}\left(\mathrm{PsO}_{2}\right)$ was first measured in babies by Huch et al. in 1972 (2). Chemically induced hyperemia did not raise $\mathrm{PsO}_{2}$ to arterial levels but in 1974, they found that thermal hyperemia did (3). Measurement of $\mathrm{PsO}_{2}$ has been routine in many nurseries since 1980 . Skin surface $\mathrm{PCO}_{2}\left(\mathrm{PsCO}_{2}\right)$ was first measured in babies by Hansen and Tooley in 1979 (4) after studies in adults assessed the effects of skin metabolism and electrode temperature (5). This technique is not yet routine in all intensive care nurseries. Oxygen saturation $\left(\mathrm{SO}_{2}\right)$ has been measured noninvasively for many years in adults (6). Both ear oximetry $(6,7)$ and, more recently, pulse oximetry (8) have been applied to babies.

Technique. $\mathrm{PsO}_{2}$ is measured with a miniature Clark electrode heated to $43-45^{\circ} \mathrm{C}$ which increases capillary blood flow by $100-$ fold (9). The in vitro time constant (the time between the onset and $63 \%$ of the pen deflection in response to a square wave change in gas concentration) is $10-20 \mathrm{~s}$ but the in vivo time constant, lengthened by diffusion through tissue, is $1-2 \mathrm{~min}(10$, 11).

$\mathrm{PsCO}_{2}$ is measured with a miniature Stow-Severinghaus $\mathrm{pH}$ electrode or metal oxide electrode. The in vitro time constant is $20-40 \mathrm{~s}$, but the in vivo time constant is about $3 \mathrm{~min}(4,5)$. $\mathrm{PsCO}_{2}$ is greater than $\mathrm{PaCO}_{2}$ due to the difference in temperature between the body and the electrode and the contribution of the skin. The temperature correction is 1.31 at an electrode temperature of $43^{\circ} \mathrm{C}$ and 1.37 at $44^{\circ} \mathrm{C}(12)$. The contribution of the skin

Received November 19, 1986; accepted November 25, 1986.

Address correspondence to Ellen M. McCann, M.S., Neonatal Services Department, Children's Hospital of San Francisco, 3700 California Street, San Francisco, CA 94118.

Supported by The National Heart, Lung, and Blood Institute (Grant HL24075), the Northern California Chapter of the National SIDS Foundation, the California Lung Association, and the Bay Area Heart Research Association. is a constant, independent of $\mathrm{PCO}_{2}$ or temperature, due to skin metabolism and other possible mechanisms (13). This difference is 3 torr in adults (5) and 2 torr in sick infants (4), but significantly greater in older babies, particularly those with chronic lung disease $(14,15)$. For both electrodes, the transit time (or delay time, the time between the appearance of gas at the membrane and the onset of pen deflection) is approximately $30 \mathrm{~s}(5,10)$.

Oximetry is a spectrophotometric technique in which red and infrared light is transmitted through the "arterialized" ear lobe, fingertip, forehead, hand, or foot (6). In early models, the photocells were next to each other resulting in errors from tissue and venous blood absorbance (6). Although smaller oximeters which alternately transmitted and received light minimized these errors, they occasionally caused burns in babies and were cumbersome (7). Pulse oximetry detects arterial pulsations and compares the absorbances of the two wavelengths during systole and diastole; there is no interference from venous blood, skin, connective tissue, or bone and no need to heat the site (8).

Applications. $\mathrm{PsO}_{2}, \mathrm{PsCO}_{2}$, and $\mathrm{SO}_{2}$ are particularly valuable during studies of variables that are affected by $\mathrm{PO}_{2}$ and $\mathrm{PCO}_{2}$. After very small decreases in inspired oxygen in babies with chronic lung disease, Halliday et al. (16) found an increase in pulmonary vascular resistance and Teague et al. (17) found an increase in airway resistance. $\mathrm{PsO}_{2}$ electrodes on the right upper chest and abdomen have been used to document right-to-left ductal shunting and $\mathrm{PsO}_{2}$ and $\mathrm{PsCO}_{2}$ are often measured during sleep studies. Recently, combined $\mathrm{PO}_{2}$ and $\mathrm{PCO}_{2}$ electrodes have been developed; these have an obvious advantage in tiny babies $(13,18)$. In very immature babies with fragile skin, a heated electrode may cause skin necrosis and saturation measurements are preferable. The sensor may be left on for 3-4 days, versus 24 hours for a $\mathrm{PsO}_{2}$ electrode.

Limitations. Halothane anesthesia interferes with the $\mathrm{PO}_{2}$ measurement when a polypropylene, but not a fluorinated ethylene propylene membrane is used. The skin surface-arterial $\mathrm{PO}_{2}$ gradient is minimal at birth but increases with age and is affected by blood flow (9). Most $\mathrm{PsCO}_{2}$ instruments allow correction for temperature but not skin metabolism. Some manufacturers recommend a correction factor of $1.5-1.7 \%$ for electrode temperatures of $44-45^{\circ} \mathrm{C} ; 1.5 \%$ is probably too high for an immature baby and too low for a baby with chronic lung disease. Corrections for both temperature and skin metabolism are preferable for babies with chronic lung disease. To make this correction, an arterial blood gas is essential. Because the puncture may cause hypo- or hyperventilation, the transit time and time constant must be known.

An averaging time is used for $\mathrm{SO}_{2}$ measurement so that beatto-beat values are not displayed. The Nellcor pulse oximeter has three averaging times: $2-3,5-7$, and $10-12 \mathrm{~s}$; the first may be underdamped and the third, overdamped. A potential danger of pulse oximetry is the failure to recognize hyperoxia which may lead to retinopathy of prematurity. Fetal hemoglobin reduces the apparent functional hemoglobin determined by oximetry; the pulse oximeter may thus show a falsely low value $(50-100 \%$ fetal hemoglobin causes a $3-4 \%$ error $)(19,20)$. 
Table 1. Pulmonary function in well and sick infants*

\begin{tabular}{|c|c|c|c|c|c|}
\hline Measurement & Units & Well infants & RDS & CLD & Source \\
\hline Tidal volume & $\mathrm{ml} / \mathrm{kg}$ & $5-7$ & $4-6$ & $4-7$ & $98,52,115$ \\
\hline Respiratory rate & breaths/min & $30-40$ & $50-80$ & $45-80$ & $98,52,115$ \\
\hline Minute ventilation & $\mathrm{ml} / \mathrm{kg} / \mathrm{min}$ & $200-300$ & $250-400$ & $200-400$ & $98,52,115$ \\
\hline Functional residual capacity & $\mathrm{ml} / \mathrm{kg}$ & $25-30$ & $20-33$ & $20-30$ & $47,52,115$ \\
\hline Thoracic gas volume & $\mathrm{ml} / \mathrm{kg}$ & $30-40$ & $20-35$ & $35-50$ & $47,46,60$ \\
\hline Dynamic compliance & $\mathrm{ml} / \mathrm{cm} \mathrm{H}_{2} \mathrm{O} / \mathrm{kg}$ & $1-2$ & $0.3-0.5$ & $0.2-0.8 \dagger$ & 52 \\
\hline Lung resistance & $\mathrm{cm} \mathrm{H}_{2} \mathrm{O} / \mathrm{liter} / \mathrm{s}$ & $25-50$ & $60-150$ & $30-150 \dagger$ & 150,86 \\
\hline Work of breathing & $\mathrm{g} \mathrm{cm} / \mathrm{min} / \mathrm{kg}$ & $500-1000$ & $800-3000 \dagger$ & $1800-6500 \dagger$ & 70,71 \\
\hline $\mathrm{P}_{\wedge} \mathrm{CO}_{2}$ & torr & $30-40$ & $32-50$ & $40-55$ & $\begin{array}{c}140,52 \\
115\end{array}$ \\
\hline $\mathrm{P}_{\wedge} \mathrm{O}_{2}$ in air & torr & $105-115$ & $92-108$ & $94-112$ & $\begin{array}{c}98,102 \\
125\end{array}$ \\
\hline Alveolar ventilation & $\mathrm{ml} / \mathrm{kg} / \mathrm{min}$ & $110-160$ & $55-90$ & $90-170 \dagger$ & 105,52 \\
\hline Physiologic dead space & $\mathrm{ml} / \mathrm{kg}$ & $2-3$ & $3.0-4.5$ & $3.0-4.5 \dagger$ & 105,52 \\
\hline Dead space/tidal volume & $\%$ & $22-38$ & $60-80$ & $35-60 \dagger$ & 105,52 \\
\hline Anatomic dead space & $\mathrm{ml} / \mathrm{kg}$ & $1.5-2.5$ & $2.5-4.2$ & $2.0-3.5 \dagger$ & 98,52 \\
\hline Alveolar dead space & $\mathrm{ml} / \mathrm{kg}$ & $0-0.5$ & $0.2-0.7$ & $0.2-1.0 \dagger$ & 105,52 \\
\hline Pulmonary clearance delay & $\%$ & $0-30$ & $7-40$ & $90-350$ & $\begin{array}{c}44,102 \\
115\end{array}$ \\
\hline $\begin{array}{l}\text { Effective pulmonary capil- } \\
\text { lary perfusion (nitrous } \\
\text { oxide) }\end{array}$ & $\mathrm{ml} / \mathrm{kg} / \mathrm{min}$ & $160-230$ & $75-140$ & $120-200 \dagger$ & 118,119 \\
\hline Venous admixture in air & $\%$ & $8-22$ & $25-60$ & $30-75$ & 102,125 \\
\hline $\mathrm{P}(\mathrm{a}-\mathrm{A}) \mathrm{CO}_{2}$ & torr & -2 to +4 & $8-25$ & $5-15 \dagger$ & 140,52 \\
\hline $\mathrm{P}(\mathrm{A}-\mathrm{a}) \mathrm{O}_{2}$ in air & torr & $20-40$ & $25-60$ & $37-69$ & 102,125 \\
\hline in $\mathrm{O}_{2}$ & torr & $230-380$ & $270-550$ & $165-465$ & 102,125 \\
\hline $\mathrm{CO}_{2}$ response & $\begin{array}{c}\mathrm{ml} / \mathrm{kg} / \mathrm{min} / \\
\text { torr } \mathrm{CO}_{2}\end{array}$ & $25-70$ & NA & NA & 145 \\
\hline
\end{tabular}

* RDS, respiratory distress syndrome; CLD, chronic lung disease; NA, not available. Ranges are $1 \mathrm{SD}$ below and above the mean for spontaneously breathing babies.

$\uparrow$ Data from our laboratory.

\section{TIDAL VOLUME AND MINUTE VENTILATION}

Definition. Tidal volume $\left(\mathrm{V}_{\mathrm{T}}\right)$ is the volume of gas inspired or expired in an average breath. Minute ventilation is the volume of gas expired in $1 \mathrm{~min}$.

Background. The first attempt to measure tidal volume and minute ventilation in babies was made in 1890 with a spirometer (21). However, it was not until 1931 that reliable measurements were made in term and preterm infants using a plethysmograph with no dead space $(22,23)$. In 1949, Cross (24) replaced the neck seal with an inflatable ring surrounding the face making the plethysmograph safer and simpler. Miller and Smull (25) used a wet test gas meter and one-way valves to measure ventilation during normoxia and hypoxia.

Because these devices are difficult to use and may affect ventilation $(26,27)$, noninvasive methods to estimate tidal volume were developed $(28,29)$. Impedance was evaluated in infants by Polgar in 1965 (30). In 1970 Milner (31) described a respiratory jacket to measure tidal volume. Induction plethysmography was first used in infants in 1981 (32).

Technique. Qualitative measurements of $\mathrm{V}_{\mathrm{T}}$ include impedance pneumographs and thermistors. In impedance pneumography, an alternating current is passed continuously across the thorax between skin electrodes. Changes in thoracic circumference and blood volume during respiration cause a change in impedance roughly proportional to tidal volume $(28-30)$. A thermistor at the proximal airway senses temperature changes caused by the flow of respiratory gas (33).

Semiquantitative methods detect changes in ventilation but may not be accurate enough to quantitate these changes. As the circumference of the thorax increases, the resistance of a mercury-in-rubber strain gauge placed around the chest changes in proportion to changes in volume (30). Respiratory inductive plethysmography uses Teflon-coated wires incorporated into bands which surround the abdomen and rib cage (32). Inductance is related to the cross-sectional area. $V_{T}=\left(A B \times I_{A B}\right)+$ $\left(\mathrm{RC} \times \mathrm{I}_{\mathrm{RC}}\right)$ where $\mathrm{AB}$ and $\mathrm{RC}$ are the abdominal and rib cage constants and $I_{A B}$ and $I_{R C}$ are the changes in inductance of the abdomen and rib cage signals. The device is calibrated with a standard quantitative method and the constants are determined. At least two markedly different sets of values for $V_{T}, I_{\Lambda B}$, and $I_{R C}$ are required (34). Semiquantitative measurements are also obtained using a jacket plethysmograph (31) or magnetometers (35).

Quantitative measurements are made with a plethysmograph, spirometer, or pneumotachograph. The plethysmograph is an airtight box into which the infant is placed with only the head, face, or airway in communication with the outside (24). During tidal breathing, the change in volume of the thorax causes a proportional change in the box pressure measured by a differential pressure transducer and tidal volume is calculated using Boyle's law. To calibrate the plethysmograph, known volumes are added and withdrawn. The related barometric technique has not been widely used (36).

Spirometry measures volume directly (37). $\mathrm{V}_{\mathrm{T}}$ subtracted or added to a water-sealed chamber causes a proportional displacement of a light-weight lid. This mechanical signal is changed to an electrical signal and recorded. If volume is recorded with respect to time, flow can be calculated.

The pneumotachograph is the most common and most practical method of measuring ventilation, particularly in sick infants. With laminar flow, the pressure drop across a resistance is linear (38). This pressure, proportional to flow, is measured by a differential pressure transducer. The flow signal is integrated with respect to time to obtain volume. A pneumotachograph suitable for the small, sick infant has a low mass, low dead space, and low resistance (39). The pneumotachograph and integrator should be validated with a spirometer to be certain that the signal 
is linear $( \pm 5 \%)$ within the expected range of flow, volume, and combined frequency of the ventilator and baby (39).

Gas concentration, humidity, and temperature affect the flow signal and must be considered during calibration (39). The pneumotachograph is attached to an endotracheal tube, nasal prongs, nasal mask, face mask, or face chamber. To minimize dead space and resistance, we have designed several pneumotachographs to replace the infant's nasal prong or endotracheal tube adaptor (Fig. 1) $(39,40)$.

Applications. Qualitative methods are used clinically to monitor ventilatory rate and recognize apnea. The thermistor may be useful in detecting obstructive apnea, especially in infants with tracheostomy tubes.

Semiquantitative methods are used both clinically and for research purposes. For example, respiratory inductive plethysmography can measure changes in ventilation accurately enough to evaluate $\mathrm{CO}_{2}$ response and other respiratory reflexes (41).

Quantitative methods are used primarily for research. Plethysmography is most useful for larger neonates; once set up, this technique allows repeated, reproducible measurements in a short period of time. The pneumotachograph is the best device for measuring ventilation in the small, sick newborn infant. The spirometer, while the most accurate, is the least used.

Limitations. Because impedance signals vary over time and with slight changes in position, the technique is only used to detect respiratory movement. Chest wall movement, and therefore a normal impedance signal, will be present with airway obstruction and no gas flow (42).

If calibrated properly, inductive plethysmography is useful and accurate in larger babies. Calibration factors may change, however, with movement of the bands or changes in the baby's position (32). We have been unable to calibrate the device in infants $<1.5 \mathrm{~kg}$ who have significant chest wall distortion.

Errors associated with plethysmography include leaks in the box or around the baby's face and temperature and humidity changes in the box. Once sealed inside, the infant is not easily accessible and may be prone to temperature instability. Apnea and aspiration are major dangers. Small, sick babies may not tolerate being moved into a plethysmograph.

Even well-designed pneumotachographs have problems; condensation, especially on the screen, causes turbulent flow and a change in calibration. This is avoided in the ventilated infant by bypassing the ventilator humidifier during the study and keeping the ambient temperature close to body temperature or by heating the pneumotachograph. Some amount of drift in the integrator baseline is unavoidable and will limit the length of time that a continuous recording of volume can be made. Drift results from improper electronic calibration or a leak in the system. The differential pressure transducer must be linear over the range of pressures being measured. The volume of gas in the transducer and connecting tubing must be equal on either side of the diaphragm. An equal pressure applied to both sides of the transducer should result in no signal. If the transducer is unbalanced, the pressure measured may be inaccurate, especially if continuous positive airway pressure or mechanical ventilation is used.

The spirometer has little use in the small, sick infant. Unless a series of one-way valves is used, there will be unacceptable rebreathing after a few breaths. Spirometry is not feasible in ventilated babies.

\section{LUNG VOLUME}

Definition. Functional residual capacity (FRC) and thoracic gas volume (TGV) are defined as the volume of gas in the lungs at the end of a tidal breath; in normal subjects they are equal. FRC is the volume of gas that communicates with the airways; TGV also includes the volume of trapped gas.

Background. In 1956, Berglund and Karlberg (43) reported results of FRC measurements by helium dilution in healthy newborns. In 1962, problems associated with rebreathing techniques were avoided by Strang and McGrath (44) who measured the FRC of healthy term infants in a plethysmograph by nitrogen wash-in after oxygen breathing. The same year, Klaus et al. (45) measured TGV by plethysmography in well infants from $7 \mathrm{~min}$ to 17 days of age. This technique was used in sick infants by Auld et al. (46). Nelson et al. (47) found that, unlike the normal adult, well babies frequently have evidence of gas trapping (TGV $>$ FRC). Because of technical problems in studying ill babies, noninvasive estimates of the changes in FRC have recently been described $(32,48,49)$.

Technique. FRC is measured with a closed circuit (rebreathing) or open circuit (nonrebreathing) apparatus. With the rebreathing method, the baby breathes from a bag containing known concentrations of oxygen and a tracer gas (helium or nitrogen) until equilibrium is reached $(30-60 \mathrm{~s})$. The final concentration of the tracer gas is measured after absorption of and correction for $\mathrm{CO}_{2}$ (50). FRC is then calculated: $F R C=\left[(\mathrm{ViCi})-(\mathrm{VfCf})-\left(\mathrm{V}_{\mathrm{D}} \mathrm{Cf}\right)\right] / \mathrm{Cf}$ where $\mathrm{Vi}$ and $\mathrm{Vf}$ are the initial and final bag volumes, $\mathrm{Ci}$ and $\mathrm{Cf}$ are the initial and final tracer gas concentrations, respectively, and $V_{D}$ is the apparatus dead space. Some investigators have added oxygen during the equilibration period $(43,51)$.

To calculate FRC by nitrogen washout, breath-by-breath $\mathrm{N}_{2}$ is measured with a rapidly responding mass spectrometer (44) or nitrogen analyzer (52) while breathing $100 \% \mathrm{O}_{2}$. FRC is obtained from the dilution factor $(w)$ and the average tidal volume minus anatomic dead space $\left(\mathrm{V}_{\mathrm{T}}-\mathrm{V}_{\mathrm{D}}\right)$ : $\left.\mathrm{FRC}=\mathrm{w}\left(\mathrm{V}_{\mathrm{T}}-\mathrm{V}_{\mathrm{D}}\right) / 1-\mathrm{w}\right)$ where $\mathrm{W}$ is the slope of a semilog plot of $\mathrm{F}_{\mathrm{A}} \mathrm{N}_{2}$ versus breath number. This may be a single or two compartment model.

Gerhardt et al. (53) calculated FRC by collection and integra-
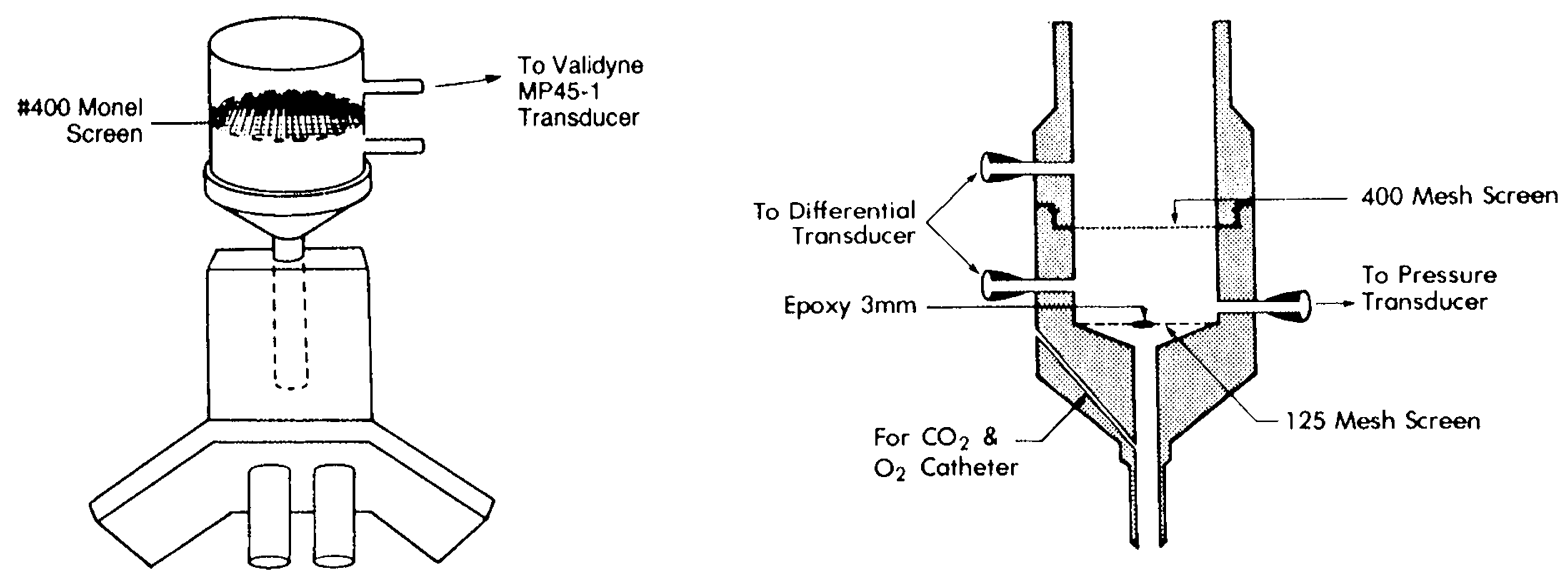

Fig. 1. Diagram of pneumotachographs that replace nasal prong and endotracheal tube adaptors. The 125-mesh screen and drop of epoxy in the endotracheal flowmeter make expiratory flow laminar. [Adapted from Goldman et al. (40) and Brady et al. (39).] 
tion of the $\mathrm{N}_{2}$ washed out with a constant flow of oxygen or a helium-oxygen mixture. Richardson et al. (54) developed a fourbreath estimate of FRC that assumes a single compartment. Richardson and Jung (55) described a new method for calculating FRC from the breath-by-breath integration and summation of expired nitrogen with respect to expiratory flow. Richardson and Anderson (56) then reported an attractive modification which minimizes hyperoxia by using only a $10-20 \%$ change in inspired oxygen. These techniques are better suited to the premature infant. We use a $20 \%$ change in inspired oxygen and calculate FRC by the dilution factor method when $V_{T}$ is constant or by summation of the product of expired nitrogen concentration and expired alveolar volume when tidal volume varies.

Ozanne et al. (57) used a mass spectrometer and on-line computer in sick adults and alternated nitrogen and argon in the washout gas mixture. Leaks were detected immediately by comparison of the results of duplicate measurements. To date, this very elegant and useful approach has not been applied to well or sick babies.

Thoracic gas volume is measured with a plethysmograph during an airway occlusion at end-expiration (45). Inspiratory effort changes box pressure (volume, $\Delta \mathrm{V}$ ) and mask pressure $(\Delta \mathrm{P})$. TGV is calculated with Boyle's law: $T G V=\left(P_{B}-P_{\mathrm{H}_{2} 0}\right) \Delta V / \Delta P$ where $\mathrm{P}_{\mathrm{B}}$ and $\mathrm{P}_{\mathrm{H}_{2} \mathrm{O}}$ are barometric and water vapor pressures, respectively. The glottis must be open for alveolar pressure to equal mask pressure.

Respiratory inductive plethysmography measures the changes in FRC noninvasively. The absolute changes in FRC are measured if tidal volume is recorded simultaneously (32). The changes in FRC are also measured during a passive exhalation following airway occlusion $(48,49)$. A plateau in mask pressure is obtained indicating a Hering-Breuer relaxation, the occlusion is quickly released, and the ensuing exhalation is analyzed. The linear portion of the flow-volume curve is extrapolated to zero, the "passive FRC" (Fig. 2A) (49). An alternative technique involves multiple occlusions. The regression of pressure and volume is plotted and extrapolated to zero, the "passive FRC" (Fig. 2B) (48).

Applications. Although a normal lung volume is critical in sick babies, it is rarely measured. Nonetheless, it has been used to assess changes in ventilator settings $(55,58)$, surfactant replacement $(52)$, and diuretic therapy $(59,60)$.

Limitations. Unlike the adult where FRC (TGV) is stable, it may vary with each breath in the preterm infant with deformable airways and chest wall. Therefore, it is difficult to obtain reproducible results and different normal values have been reported. Rebreathing techniques are particularly difficult to use in ill babies requiring high ventilatory pressures. In babies with poor distribution of ventilation, equilibration time is prolonged and rebreathing causes hypoxia and hypercarbia. Leaks are a great source of error; Fox et al. (61) described a method that mathematically corrects for leaks and some investigators use cuffed endotracheal tubes. Finally, helium analyzers must be corrected for the effects of high oxygen.

The use of $100 \%$ oxygen for nitrogen washout may cause significant hyperoxia and may result in absorption atelectasis in areas with a low ventilation/perfusion ratio (62). Some FRC calculations require a relatively constant tidal volume and an accurate calculation of anatomic dead space (44). The integrated $\mathrm{N}_{2}$ washout described by Gerhardt et al. (53) can be performed on intubated babies but not mechanically ventilated babies. It has the advantage of using oxygen-helium mixtures, but some nitrogen analyzers and mass spectrometers are inaccurate when $>10 \%$ helium is present.

Helium-oxygen breathing decreases airway resistance in babies with chronic lung disease (63); it is not known whether this changes FRC. In babies with chronic lung disease and subglottic stenosis, Butt et al. (64) reported a decrease in oxygenation during breathing $70-80 \%$ helium in oxygen which was not seen when continuous positive airway pressure was given, suggesting that FRC might have changed.

Thoracic gas volume measured by plethysmography is impractical for sick babies and is prone to errors due to leaks and changes in water vapor pressure. Klaus et al. (45) used a reference volume as an internal check. Godfrey et al. (65) found that TGV was underestimated in babies with bronchiolitis and questioned whether it can be measured accurately when the airways are obstructed.

Inductive plethysmography is useful for following TGV changes over the short term. Long-term studies require an automatic baseline return (AC coupling) which obliterates the changes in end-expired volume. The occlusion method for "passive FRC" is ideal for spontaneously breathing babies but more difficult to apply in mechanically ventilated babies. Valves which add dead space and resistance are required. Leaks around the endotracheal tube make a pressure plateau impossible to achieve.

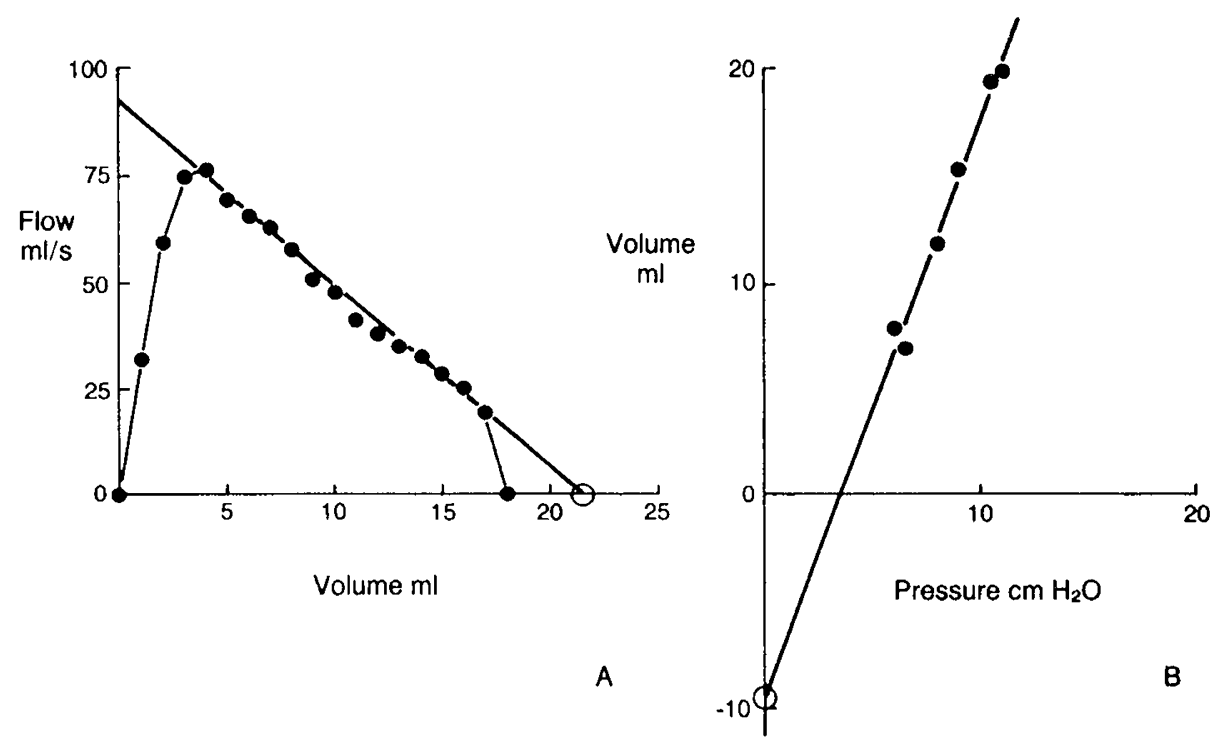

Fig. 2. Calculation of "passive FRC" and the passive mechanics of the respiratory system in a 2-kg well premature baby. $A$, passive exhalation following airway occlusion. The slope of the flat portion is the time constant of the respiratory system, $0.23 \mathrm{~s}$, and the X-intercept is the "passive FRC." $B$, the regression of volume and pressure obtained with multiple airway occlusions. The slope of the line is the compliance of the respiratory system, $2.7 \mathrm{ml} / \mathrm{cm} \mathrm{H}_{2} \mathrm{O}$, and the $\mathrm{Y}$-intercept is the "passive FRC." 


\section{MECHANICS OF RESPIRATION}

Definition. Compliance reflects the elastic properties of the respiratory system and is defined as the change in volume per unit change in pressure $\left(\mathrm{ml} / \mathrm{cm} \mathrm{H}_{2} \mathrm{O}\right)$. The compliance of the total respiratory system (Crs) can be divided into lung compliance $\left(C_{1}\right)$ and chest wall compliance $(\mathrm{Ccw})$ where $1 / \mathrm{Crs}=1 / \mathrm{C}_{\mathrm{L}}$. $+1 / \mathrm{Ccw}(66)$.

Resistance of the respiratory system (Rrs) is a reflection of the friction encountered by gas flowing through the airways and by tissue moving against tissue. It is defined as the change in pressure required for a unit change in flow $\left(\mathrm{cm} \mathrm{H}_{2} \mathrm{O} / \mathrm{L} / \mathrm{s}\right)$. Rrs is the sum of airway resistance (Raw), lung tissue resistance (Rlt), and chest wall tissue resistance (Rcw). Lung resistance $\left(R_{L}\right)$ is the sum of Raw and Rlt (67). Conductance is the inverse of resistance.

Work of breathing integrates the elastic and resistive properties and is equal to the cumulative product of pressure and the volume of air moved at each instant: Work $=\int$ PdV (67).

Background. Observations on the mechanical properties of the newborn infant's lungs were made by Karlberg et al. in 1954 (68). Using a $1-\mathrm{mm}$ diameter polyethylene tube, they found that infants with respiratory distress syndrome had greater esophageal pressure changes than did normal infants. In 1955, using a body plethysmograph, pneumotachograph, and esophageal catheter, Mcllroy and Tomlinson (69) calculated work of breathing and "elastic resistance" in 12 infants, three of whom were premature.

Cook et al. (70) described classical methods for measuring compliance and resistance and reported normal values in well
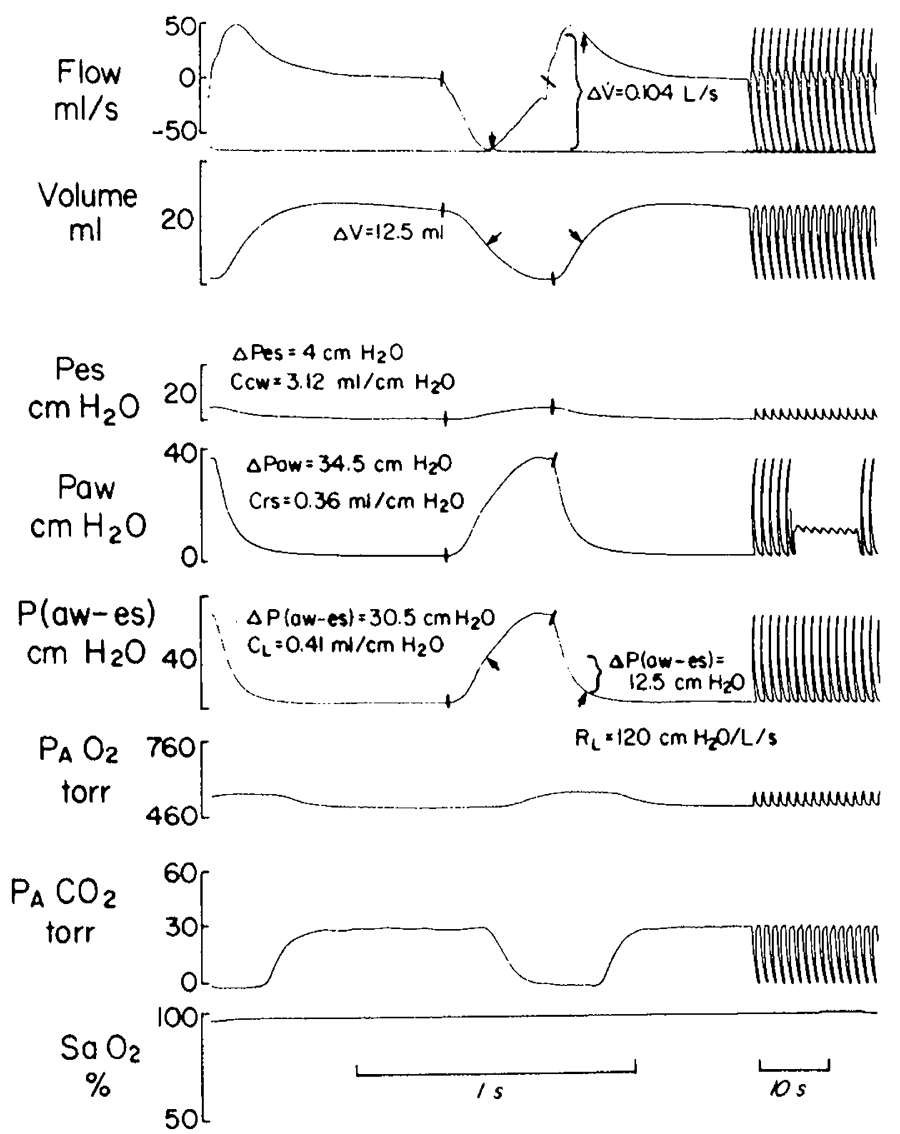

Fig. 3. Calculation of mechanics of ventilation in a $1.2-\mathrm{kg}$ infant with severe chronic lung disease. Measurements at points of zero flow ( | ) are used to calculate chest wall compliance $(C \mathrm{cw})$, respiratory system compliance $(C r s)$, and lung compliance $\left(C_{t}\right)$. Measurements corresponding to mid-tidal volume $(\uparrow)$ are used to calculate lung resistance $\left(R_{l}\right.$, the sum of airway resistance and lung tissue resistance). Mean airway pressure, obtained by electrical damping of the airway pressure signal, is $11 \mathrm{~cm}$ $\mathrm{H}_{2} \mathrm{O}$. and sick infants. Swyer et al. (71) were among the first to use a face-mask pneumotachograph and esophageal balloon to calculate mechanics of breathing.

Technique. Calculations of lung mechanics require the measurement of the pressure affecting the lung component of interest. For example, to calculate the respiratory system compliance of an infant receiving positive pressure ventilation, the changes in airway pressure (Paw) are measured and to calculate lung compliance, the changes in transpulmonary pressure (the pressure difference between the airway and the pleural space) are measured (Fig. 3).

Because direct measurement of plcural pressure is not feasible, it is estimated with esophageal pressure (Pes) (72-74). Esophageal pressure is measured with a pressure transducer attached to either a balloon catheter or a fluid-filled catheter in the lower third of the esophagus. Balloons can be handmade $(73,75)$ or manufactured $(6.5 \mathrm{~mm}$ wide, $30 \mathrm{~mm}$ long, $0.06 \mathrm{~mm}$ wall thickness, Alto Development Company). We double tie the balloon to an 8 -Fr feeding tube with six side holes and connect it to a pressure transducer (Gould Statham PM131TC) with $50 \mathrm{~cm}$ of PE205 tubing.

The accuracy of the measurement is affected by the balloon and catheter dimensions, the frequency response of the pressure transducer and catheter system, and the volume of air in the balloon. All these must be assessed in vitro with the equipment configuration used for the study. We have found that $8-\mathrm{Fr}$ catheters are adequate (Fig. 4) but that 5-Fr catheters are not (Fig. 5). The 5-Fr balloon catheter signal in Figure 5 is signifi-
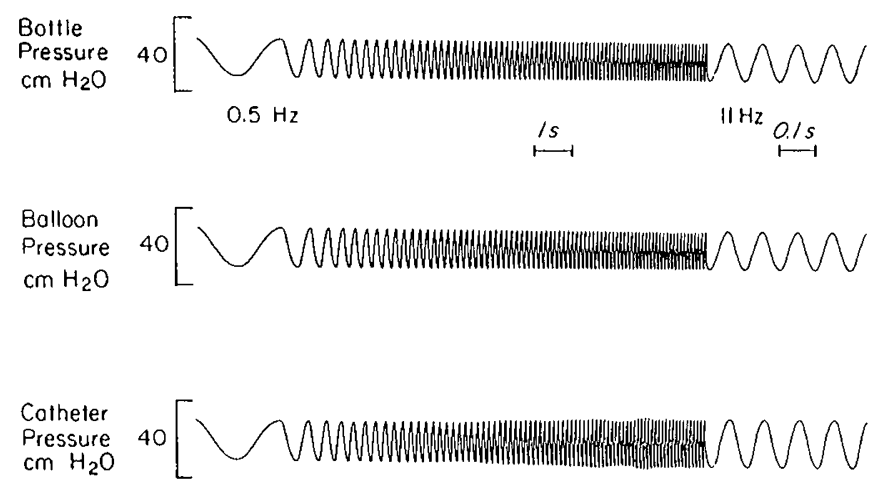

Fig. 4. Response of pressure transducers and 8-French catheter systems to changes in frequency from $0.5-11 \mathrm{~Hz}$. The balloon pressure signal is from a $6.5 \times 30 \mathrm{~mm}$ balloon attached to an 8 -French feeding tube and the catheter signal is from a water-filled 8-French feeding tube, both with six side holes. The frequency response for all signals is linear $( \pm 5 \%)$ to $11 \mathrm{~Hz}$.
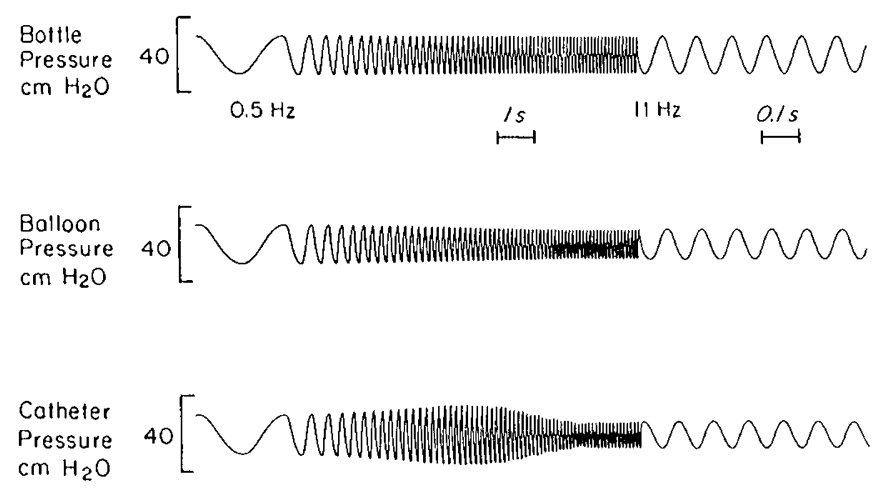

Fig. 5. Response of pressure transducers and 5-French catneler systems to changes in frequency from $0.5-11 \mathrm{~Hz}$. With the same balloon as in Figure 4 , but now attached to a 5-French feeding tube, the signal is overdamped at frequencies $>6 \mathrm{~Hz}$. The water-filled 5-French catheter signal is underdamped at frequencies $>4 \mathrm{~Hz}$ and overdamped at frequencies $>9 \mathrm{~Hz}$. 
cantly overdamped at frequencies $>6 \mathrm{~Hz}$; the 5 -Fr fluid-filled catheter signal is underdamped at frequencies $>4 \mathrm{~Hz}$ and overdamped at frequencies $>9 \mathrm{~Hz}$. A flat frequency response $( \pm 5 \%)$ to 10 times the fundamental frequency is required. The correct amount of air inside the balloon is determined by constructing a pressure-volume curve as described by Beardsmore et al. (75). The volumes which produce a negligible change in balloon pressure are appropriate. To evaluate its accuracy in vivo, the balloon or catheter is positioned in the lower third of the esophagus and an occlusion test is performed (75). During an occluded inspiratory effort, the pressure measured at the proximal airway should equal $( \pm 5 \%)$ the esophageal (alveolar or pleural) pressure.

Measurement of static compliance is not practical in sick infants and therefore the pressure used to overcome the respiratory system's elastance must be distinguished from that used to overcome its resistance. At end-inspiration and end-expiration there is no flow and therefore no resistance. The changes in volume and pressure at these points are used to calculate dynamic compliance (Fig. 3). Static compliance may be approximated if the infant is receiving positive pressure ventilation and has minimal spontaneous respiratory effort by sustaining the inspiratory pressure plateau for approximately $1 \mathrm{~s}(76)$.

In the newborn, $\mathrm{Crs}$ approximates $\mathrm{C}_{\mathrm{l}}$ ( $\mathrm{Ccw}$ is high and $1 / \mathrm{Ccw}$ is very low) and its measurement avoids the estimation of pleural pressure. Tepper $e t$ al. (77) used the weighted spirometer technique in infants. A weight placed on the bell of the spirometer produces a continuous positive pressure $(\Delta \mathrm{P})$ which causes an increase in end-expiratory volume $(\Delta V)$. The technique assumes that the increased pressure completely equilibrates within the lung.

Teague et al. (78) modified a constant flow method for measuring Crs in mechanically ventilated infants. The technique is based on the principle that gas flowing into a container at a constant rate causes a constant increase in pressure that is inversely proportional to the compliance of the container. The ventilator flow rate during inspiration $(\mathrm{ml} / \mathrm{s})$ divided by the slope of the airway pressure tracing $\left(\mathrm{cm} \mathrm{H}_{2} \mathrm{O} / \mathrm{s}\right)$ equals the "pulse" compliance of the respiratory system.

In spontaneously breathing infants, not all of the pressure generated by the inspiratory muscles is used efficiently; some is wasted in distortion of the chest wall. Thus, in the immature infant with the most deformable chest wall, compliance may be underestimated (48). The magnitude of this wasted pressure can be determined by comparing the passive compliance of the respiratory system with dynamic compliance. Passive compliance is calculated during respiratory muscle relaxation $(48,49$, $79,80)$. The airway is occluded during expiration at different lung volumes and the proximal airway pressure (or mouth pressure) is plotted against volume; the slope of the linear regression represents compliance (Fig. $2 B$ ) (48). In spontaneously breathing infants, relaxation of the respiratory muscles is induced with the Hering-Breuer reflex (49).

To calculate resistance, the change in flow and the corresponding change in pressure must be measured. As with the calculation of compliance, the pressure used to overcome resistance must be differentiated from that used to overcome elastance. To do this, a pressure-volume loop is constructed (Fig. 6) (81). The slope of the line $\mathrm{AC}$ is the lung compliance and the distances EB and ED are the additional pressures needed to overcome airway and tissue resistance during inspiration and expiration. Because compliance is not always linear (82), it is better to calculate total resistance, the sum of inspiratory and expiratory resistance. A second method uses the flow, volume, and pressure tracings (Fig. $3)$. $R_{1}$, is calculated using the differences in transpulmonary pressure, $\mathrm{P}(\mathrm{aw}-\mathrm{es})$, and flow at equal volume points during inspiration and expiration. At equal volumes, elastic components should be equal and opposite; mid-tidal volume is usually used (83).

Airway resistance is measured using the plethysmograph (84). The driving pressure is the alveolar pressure inferred from the

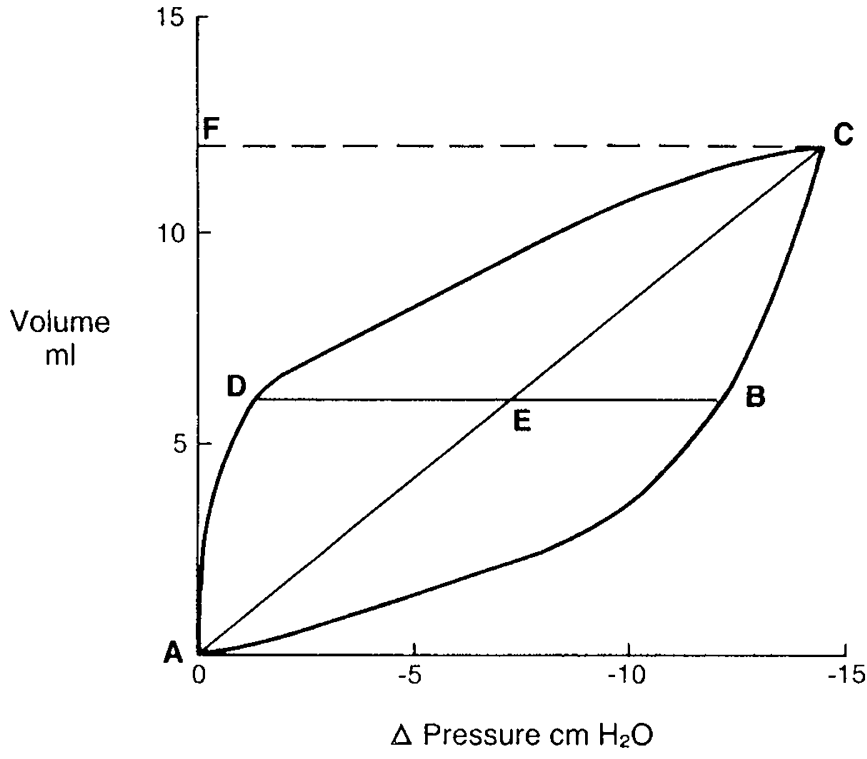

Fig. 6. Pressure-volume loop for calculation of mechanics of ventilation in a 1.6-kg infant with chronic lung disease. The slope of line $\mathrm{AC}$ is lung compliance, $0.86 \mathrm{ml} / \mathrm{cm} \mathrm{H}_{2} \mathrm{O}$. The distances EB and ED represent the additional inspiratory and expiratory pressures needed to overcome airway and tissue resistance. The distance DB divided by the difference in flow at those points is equal to the total lung resistance, $150 \mathrm{~cm} \mathrm{H}_{2} \mathrm{O}$ / liter/s. The work of breathing, the area $\mathrm{ABCF}$, is $145 \mathrm{~g} \mathrm{~cm} / \mathrm{breath}$.

pressure change within the box. The flow is measured directly with a pneumotachograph or calculated from the volume tracing. The adult subject must pant during this measurement because large breaths may cause an artifact due to temperature and humidity. As infants cannot pant voluntarily, a heated rebreathing system was developed by Stocks et al. (85).

Respiratory system resistance is calculated using the techniques for passive Crs $(48,49,79,80)$. The slope of the linear portion of the expiratory flow-volume curve is the respiratory system time constant, the product of $\mathrm{Crs}$ and Rrs (Fig. 2A). If $\mathrm{Crs}$ is known, Rrs can be calculated.

Work of breathing is calculated by constructing a pressurevolume loop and measuring the area (Fig. 6). The area can be measured by hand; we use a microcomputer and digitizer. There are several equations that estimate the work of breathing (70). Mcllroy used the formula: Work $=0.6 \mathrm{PV}_{\mathrm{T}}$ where $\mathrm{P}$ is the peak pressure generated. The formula assumes that the pressure is a sine wave and that $70 \%$ of total work is elastic.

Applications. All of these techniques have been used to study small, sick infants. We have evaluated the effects of disease state, medication, and mechanical ventilation on respiratory mechanics (40, 86-88). Recently available computerized systems have the potential for routine clinical use. Modifications of resistance measurements such as flow-volume curves with gases of different densities and viscosities have been used to diagnose small airway disease in infants (89).

Limitations. It is extremely important that all of the instruments be properly calibrated, balanced, and in phase. Because the calculations use the temporal relationships of two to three variables, any equipment problems will be magnified (90). The rigorous quality control needed is described by Beardsmore $e t$ al. (75). A major limitation of many techniques is the estimation of intrapleural pressure by esophageal pressure. Air bubbles or mucus in the fluid-filled catheter lead to inaccurate measurements. LeSoueff et al. (91) demonstrated that pleural pressure is unevenly distributed around the esophagus, especially in premature infants with significant chest wall distortion. In these infants, results of the occlusion test are variable. Beardsmore et al. (92) demonstrated that when FRC is significantly increased 
or when positive pressure is used, Pes may not reliably estimate pleural pressure. The occlusion technique for verifying Pes assumes that there is instantaneous equilibration of pressure throughout the airways. This is not true with heterogeneous time constants or with partial airway obstruction (93-95).

Even if accurate measurements of compliance and resistance are made, their significance may be limited if the lung volume is not known. Compliance is greatly affected by lung volume; an over- or underdistended lung has a lower compliance. As the lung grows, the compliance of the whole lung increases, whereas the compliance of each lung unit is relatively constant. Thus the low compliance measured in infants with respiratory distress syndrome is due, in part, to smaller lung volumes. Specific compliance (compliance/FRC) or compliance $/ \mathrm{kg}$ is more meaningful $(1,76)$.

The effect of lung volume on resistance is equally critical. As lung volume decreases, resistance increases exponentially. This relationship is more conveniently illustrated using conductance as there is a direct linear relationship between conductance and lung volume. Resistance or conductance should also be standardized using FRC (specific conductance), weight, or length (1, 76). When conductance is compared in premature infants of different gestational ages, its relationship to age should be considered. Stocks and Godfrey (96) demonstrated that there was a rapid decrease in specific conductance until $40 \mathrm{wk}$ postconceptual age. An additional limitation is the effect of resistance on dynamic compliance. If airway resistance is elevated or the breathing rate is rapid, dynamic compliance will be falsely lowered; this is termed frequency dependence of compliance (97).

\section{ALVEOLAR GAS TENSIONS AND ALVEOLAR VENTILATION}

Definition. Alveolar gas tensions are the partial pressures of $\mathrm{O}_{2}, \mathrm{CO}_{2}$, and $\mathrm{N}_{2}$ in alveolar gas; they are estimated with endtidal gas tensions. Alveolar ventilation is the volume of inspired gas that takes part in gas exchange with pulmonary capillary blood. Wasted ventilation is the volume of inspired gas that does not take part in gas exchange and only comes in contact with dead space. Dead space consists of conducting passages (anatomic dead space), nonperfused or underperfused alveoli (alveolar dead space), and equipment dead space.

Background. Early estimations of end-tidal gas tensions were made on gas withdrawn from a miniature Rahn sampler (98). Although the sampler dead space was small, the total equipment dead space was large, resistance was high, and contamination with dead space gas was possible. These problems were avoided with continuous measurement of inspired and expired gas by Strang (99) in well babies using a mass spectrometer and Chu et al. (52) in sick babies with $\mathrm{N}_{2}$ and $\mathrm{CO}_{2}$ analyzers in series. When a rapidly responding $\mathrm{O}_{2}$ analyzer became available, all three gases were measured simultaneously (100). The concept of ideal alveolar gas tensions (101) was applied to well and sick babies by Nelson et al. (102). Ideal alveolar $\mathrm{PCO}_{2}$ was assumed to equal arterial $\mathrm{PCO}_{2}$ and ideal alveolar $\mathrm{PO}_{2}$ was calculated with the alveolar gas equation. Corbet et al. (103) used this method to calculate alveolar $\mathrm{PN}_{2}$ and measured arterial $\mathrm{PN}_{2}$ by gas chromatography in well and sick babies.

The first calculations of alveolar ventilation were reported by Karlberg et al. (68) in 1954 using the plethysmograph and arterial $\mathrm{PCO}_{2}$. Mixed-expired $\mathrm{CO}_{2}$, diluted in 5-6 liters of gas, was measured with the Scholander method. In 1961, Strang (99) used a plethysmograph, mass spectrometer, and the graphical method of Fowler (104) to measure anatomic dead space in well newborns. Nelson et al. $(98,105)$ measured both anatomic and physiologic dead space in well and sick infants using their endtidal sampler, a spirometer, and arterial $\mathrm{PCO}_{2}$. Chu et al. (52) calculated physiologic and anatomic dead space with the Bohr equation in very ill babies using arterial $\mathrm{PCO}_{2}$, end-tidal $\mathrm{PCO}_{2}$, and mixed-expired $\mathrm{PCO}_{2}$ obtained either by hand integration of the expired $\mathrm{CO}_{2}$ tracing with respect to volume or by collection of expired gas.
Technique. Alveolar gas tensions are very difficult to measure in the sick baby with a rapid breathing rate and irregular tidal volume. In ill babies, the alveoli may not empty uniformly making end-tidal tensions poor estimations of alveolar tensions (Fig. 7). Gas analyzers and mass spectrometers require a gas sampling rate of approximately 70 and $15 \mathrm{ml} / \mathrm{min}$, respectively. We only accept end-tidal values when the mean expiratory flow rate is more than six times the sampling rate and the end-tidal plateau is more than three times the time constant of the gas analyzers and sampling system. This latter condition may not be achieved when the breathing rate is $>90 / \mathrm{min}$.

The transit time and time constant are affected by the sampling rate, the catheter and connecting tubing dimensions, and the vacuum system. We use $75 \mathrm{~cm}$ of unheated polyethylene tubing (0.38 mm ID) and Duo-Seal pump with $\mathrm{CO}_{2}$ (Beckman LB2) and $\mathrm{O}_{2}$ (Applied Electrochemistry S3A) analyzers connected in series (39). A powerful vacuum pump is required to create a pressure of -660 torr in the $\mathrm{CO}_{2}$ sample cell (106). A second Duo-Seal pump draws gas through a needle valve interposed between the $\mathrm{O}_{2}$ and $\mathrm{CO}_{2}$ analyzers to the $\mathrm{N}_{2}$ analyzer (Med Science 505). The transit time and time constant must be measured in vitro with a square wave change of flow and gas concentrations (Fig. 8). For these measurements, the polygraph pens should be in phase and the equipment in the configuration used for the study.

Ideal alveolar gas tensions (those present when there is no wasted ventilation or wasted perfusion) are calculated with the alveolar gas equation: $\mathrm{P}_{\Lambda} \mathrm{O}_{2}=\mathrm{P}_{1} \mathrm{O}_{2}+\left[\mathrm{P}_{\Lambda} \mathrm{CO}_{2} \mathrm{~F}_{1} \mathrm{O}_{2}(\mathrm{l}-\mathrm{RQ}) / \mathrm{RQ}\right]$ - $\left(\mathrm{P}_{\Lambda} \mathrm{CO}_{2} / \mathrm{RQ}\right)$ where $\mathrm{P}_{\Lambda} \mathrm{O}_{2}$ and $\mathrm{P}_{1} \mathrm{O}_{2}$ are alveolar and inspired $\mathrm{PO}_{2}$, respectively, $\mathrm{P}_{\Lambda} \mathrm{CO}_{2}$ is the alveolar $\mathrm{PCO}_{2}$ assumed to equal arterial $\mathrm{PCO}_{2}, \mathrm{~F}_{1} \mathrm{O}_{2}$ is the fraction of inspired $\mathrm{O}_{2}$ and $\mathrm{RQ}$ is the respiratory quotient. The respiratory quotient, $\mathrm{CO}_{2}$ output divided by $\mathrm{O}_{2}$ intake, has been measured $(98,107)$ or estimated (103).

As alveolar ventilation $\left(\dot{V}_{\wedge}\right)$ represents the portion of minute ventilation that reaches perfused alveoli, it is inversely proportional to $\mathrm{PCO}_{2}: \dot{\mathrm{V}}_{\mathrm{\Lambda}}=\dot{\mathrm{V} C O} \mathrm{O}_{2}(863) / \mathrm{P}_{\Lambda} \mathrm{CO}_{2}$ where $\dot{\mathrm{V}}_{\Lambda}$ is in $\mathrm{ml} / \mathrm{min}$ BTPS, $\dot{\mathrm{V} C O} \mathrm{C}_{2}$ is the $\mathrm{CO}_{2}$ output in $\mathrm{ml} / \mathrm{min}$ STPD, $\mathrm{P}_{\wedge} \mathrm{CO}_{2}$ is the alveolar $\mathrm{PCO}_{2}$, assumed to equal arterial $\mathrm{PCO}_{2}$, and 863 is a constant which converts $\dot{\mathrm{V} C O}$ to BTPS and the fraction of $\mathrm{CO}_{2}$ to the partial pressure. The first measurements of alveolar ventilation in babies were made in this way $(68,107)$. As arterial $\mathrm{PCO}_{2}$ was used, physiologic dead space was calculated.

When rapidly responding mass spectrometers and gas analyzers are available, the Bohr equation is used to calculate dead space: $\mathrm{V}_{\mathrm{D}} / \mathrm{V}_{\mathrm{T}}=\left(\mathrm{P}_{\Lambda} \mathrm{CO}_{2}-\mathrm{P}_{\mathrm{E}} \mathrm{CO}_{2}\right) / \mathrm{P}_{\Lambda} \mathrm{CO}_{2}$ where $\mathrm{P}_{\Lambda} \mathrm{CO}_{2}$ and $\mathrm{P}_{1} \mathrm{CO}_{2}$ are alveolar and mixed-expired $\mathrm{PCO}_{2}$, respectively. When ideal $\mathrm{P}_{\Lambda} \mathrm{CO}_{2}$, estimated by arterial $\mathrm{PCO}_{2}$ is used, physiologic dead space is calculated; when end-tidal $\mathrm{PCO}_{2}$ is used, anatomic dead space is calculated. We determine the mixed-expired $\mathrm{PCO}_{2}$ with the integration method of Chu et al. (52) assisted by a computer and digitizer. Chu et al. (52) found that the time constant correction resulted in a difference of $<5 \%$. We find a $5 \%$ error

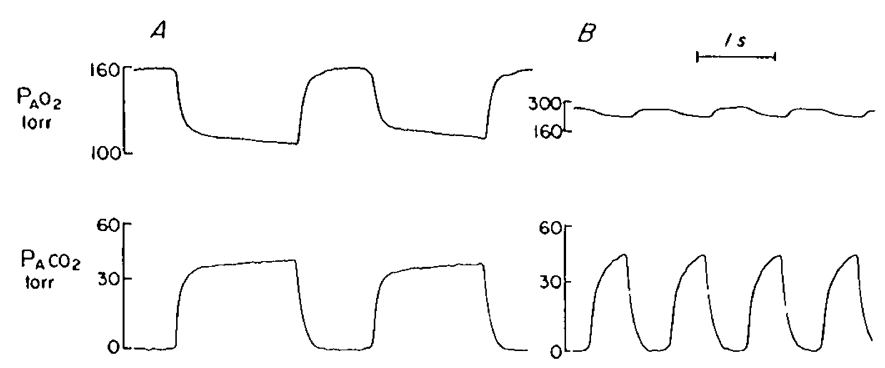

Fig. 7. End-tidal $\mathrm{PO}_{2}$ and $\mathrm{PCO}_{2}$ in an 11 -wk-old term baby with normal lungs $(A)$ and an 11 -wk-old premature baby (28 wk gestation) with severe chronic lung disease $(B)$. Note the normal $\mathrm{PCO}_{2}$ and good alveolar plateaus in $\mathrm{A}$ contrasted with the high $\mathrm{PCO}_{2}$, rapid breathing rate, and absence of alveolar plateaus in $\mathrm{B}$. 


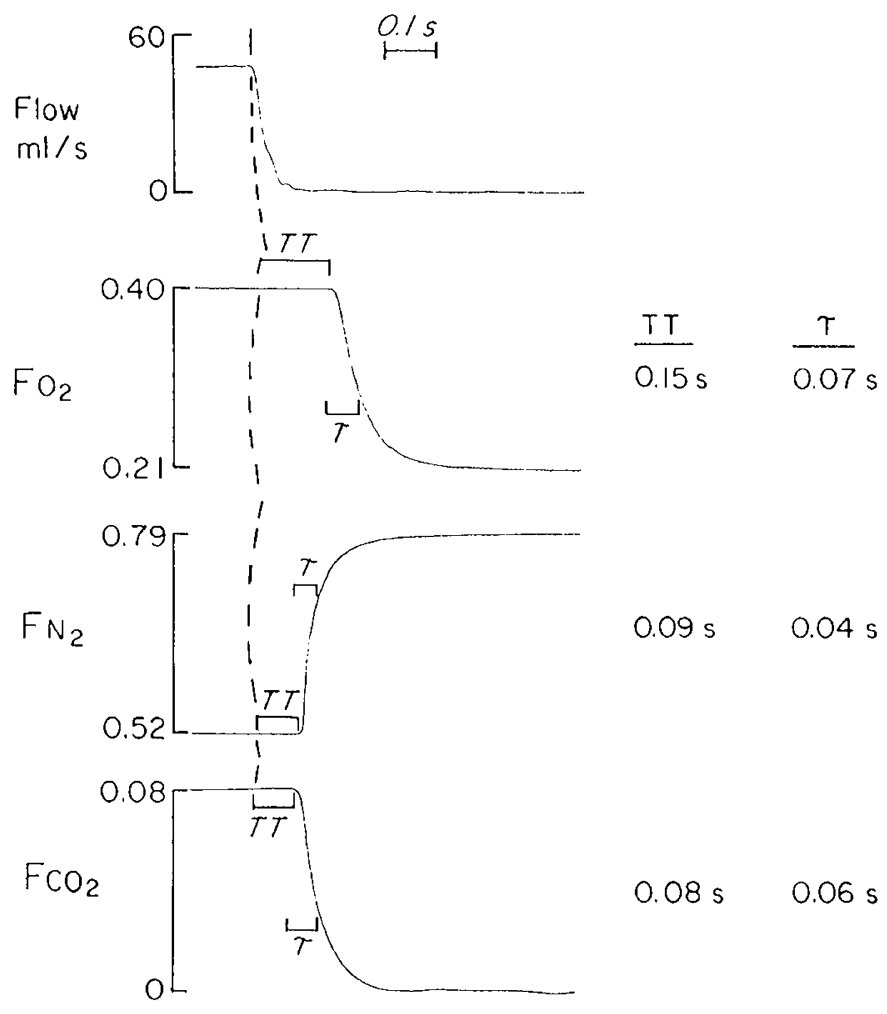

Fig. 8. Calculation of transit time and time constant for alveolar gas tensions. The dotted line marks the event, a square wave change in flow. The transit time (TT) is the time between the change in flow and the onset of pen deflection. The time constant $(\tau)$ is the time between the onset and $63 \%$ of the total pen deflection.

when the breathing rate is $30-60 / \mathrm{min}$ but a $25 \%$ error when it is $>80 / \mathrm{min}$ and therefore apply it in every case.

Applications. Although alveolar ventilation is critical for gas exchange, it is rarely measured; the $\mathrm{PaCO}_{2}$ is commonly used to estimate it. End-tidal gas tensions and alveolar ventilation measurements have been used to study the effects of surfactant replacement and diuretic therapy in sick babies $(52,87)$.

Limitations. In babies with severe maldistribution of ventilation, it may be impossible to obtain alveolar plateaus (Fig. 7) and calculation of ideal alveolar $\mathrm{PO}_{2}$ is preferable. However, calculated ideal tensions are not always alveolar tensions. Corbet et al. assumed that the arterial-alveolar $\mathrm{PCO}_{2}$ difference was zero in normal infants and 15 torr in sick infants (103). The respiratory quotient is usually assumed to be 0.7 or 0.8 and small deviations from this result in only small differences for $\mathrm{P}_{\wedge} \mathrm{O}_{2}$.

\section{DISTRIBUTION OF VENTILATION}

Definition. Tests of the distribution of ventilation measure how evenly or unevenly inspired gas is distributed to all areas of the lung.

Background. Strang and McGrath (44) were the first to measure distribution of ventilation in well newborns. They used nitrogen wash-in after oxygen breathing and calculated pulmonary clearance delay as described by Fowler et al. (108). The following year, Nelson et al. (102) made these measurements in sick newborns. More recently, radioactive tracers have been used to assess the distribution of ventilation $(109,110)$.

Technique. Most tests of the distribution of ventilation are based on measuring how efficiently a tracer gas is removed from the lung (washed out) or equilibrated within the lung (washed in). Mathematical expressions of this efficiency include pulmonary clearance delay, inspired gas distribution index, and moment analysis $(108,111,112)$.
Nelson et al. (102) used the method of Briscoe and Cournand (113) in which gas is sampled from the Rahn end-tidal sampler and $\mathrm{F}_{\wedge} \mathrm{N}_{2}$ plotted on semilog paper as a function of time. When mass spectrometers and gas analyzers with suitable sampling rates are available, the method of Fowler et al. (108) is used. A semilog plot of $\mathrm{F}_{\wedge} \mathrm{N}_{2}$ versus breath number is analyzed and the pulmonary clearance delay $(\mathrm{PCD})$ is calculated: $\mathrm{PCD}=[$ (actual breath number-ideal breath number)/ideal breath number] $\times$ $100 \%$. The breath numbers are calculated from the semilog plot and represent the average number of breaths required to remove a molecule of gas. Hanson and Shinozaki (111) measured cumulative alveolar ventilation and calculated the inspired gas distribution index, the ratio between the ideal and actual cumulative alveolar ventilation values required to reduce $\mathrm{F}_{\wedge} \mathrm{N}_{2}$ to 0.02 . Weygandt (114) described a five-breath index of the distribution of ventilation. This attractive technique reduces the duration of hyperoxia, but has not been used in babies.

Applications. Distribution of ventilation is commonly measured in adults but only rarely in babies. It is markedly abnormal in babies with chronic lung disease and may become a very important measurement as this population grows (115). Pulmonary clearance delay is most useful for studying these babies and their response to therapy. Heaf et al. (110) used ${ }^{81} \mathrm{Kr}$ ventilation scans in babies with unilateral lung disease and found, in contrast to the adult, that gas exchange was improved with the good lung uppermost.

Limitations. The calculation of pulmonary clearance delay by the method of Fowler et al. (108) depends on the accurate determination of mixed-expired $\mathrm{N}_{2}$ or end-tidal $\mathrm{N}_{2}$. When severe maldistribution of ventilation is present, end-tidal plateaus may not be obtained. As oxygen breathing may result in resorption atelectasis, areas of low ventilation/perfusion ratio may not be detected (62).

The use of radioisotopes is limited. The half-life of ${ }^{13} \mathrm{~N}$ is 10 $\min ;{ }^{81} \mathrm{Kr}$ has a low radiation dose and is eluted from ${ }^{81} \mathrm{Rb}$ (halflife, $4.6 \mathrm{~h}$ ). ${ }^{133} \mathrm{Xe}$ has a high radiation dose and is soluble in tissues permitting only single views. These techniques are rarely used for research because of ethical and technical considerations.

\section{PERFUSION AND THE VENTILATION/PERFUSION RELATIONSHIP}

Definition. Pulmonary capillary perfusion $(\dot{\mathrm{Qpc}})$ is the volume of blood flowing through the lungs, composed of blood that participates in gas exchange (effective) and that which perfuses nonventilated or underventilated alveoli (shunted).

The $\mathrm{PO}_{2}$ and $\mathrm{PCO}_{2}$ of blood leaving the lungs depend not on ventilation alone or perfusion alone, but on the relationship between alveolar ventilation and pulmonary capillary perfusion (67). When there is perfect matching of ventilation and perfusion, there is virtually no wasted ventilation or wasted perfusion. The pioneering work of Riley and Cournand (101), Rahn and Fenn (116), and West (117) in understanding the importance of this relationship has been applied to well and sick babies by examining alveolar-arterial gas differences and the measured or calculated ventilation/perfusion ratio.

Background. Effective pulmonary capillary perfusion has been measured in well and sick babies using the soluble gases freon (52) and nitrous oxide $(118,119)$. The total shunt fraction (venous admixture) has been calculated in well and sick babies with the Berggren equation (120). Cardiac catheterization and injection of radioactive tracers have been used to measure total pulmonary blood flow (76).

The ventilation/perfusion relationship was first assessed in babies with the alveolar-arterial differences for $\mathrm{CO}_{2}, \mathrm{O}_{2}$, and $\mathrm{N}_{2}$. Using the arterial-alveolar $\mathrm{PCO}_{2}$ difference, Nelson et al. (105) suggested that the lung of the newborn $w$ ith respiratory distress is overventilated relative to perfusion ard, using the alveolararterial $\mathrm{PO}_{2}$ differences in air and oxygen, they suggested that there was a significant right-to-left shunt in well and sick babies 
(102). This latter finding was not confirmed by Ledbetter et al. (121) who found significant mismatching of ventilation and perfusion (rather than right-to-left shunt) in well babies as evidenced by a high urinary-alveolar $\mathrm{PN}_{2}$ difference; urinary $\mathrm{PN}_{2}$ was used to estimate arterial $\mathrm{PN}_{2}$.

Technique. For the noninvasive measurement of effective pulmonary capillary perfusion (Q்p eff), the baby rebreathes from a bag containing a known amount of nitrous oxide in oxygen. $V_{T}$ is measured with a flowmeter or spirometer $(118,119)$. The decrease in gas concentration is proportional to the effective pulmonary capillary perfusion, the solubility of the gas in blood, and the lung volume. Qpc eff $=\left(\dot{\mathrm{VN}}_{2} \mathrm{O}\right) 60 / \mathrm{F}_{\wedge} \mathrm{N}_{2} \mathrm{O} \lambda \mathrm{t}$ where $\dot{\mathrm{V}} \mathrm{N}_{2} \mathrm{O}$ is the $\mathrm{N}_{2} \mathrm{O}$ uptake in ml during $\mathrm{t} s, \mathrm{~F}_{\mathrm{A}} \mathrm{N}_{2} \mathrm{O}$ is the mean alveolar $\mathrm{N}_{2} \mathrm{O}$ concentration, and $\lambda$ is the solubility of $\mathrm{N}_{2} \mathrm{O}$ in cord blood in $\mathrm{ml} \mathrm{N} \mathrm{N}_{2} \mathrm{O} / \mathrm{ml}$ blood. The percent of shunted blood is calculated with the Berggren equation: $\dot{\mathrm{Q} s} / \dot{\mathrm{Q}} \mathrm{t}=\left(\mathrm{CC}_{2}-\right.$ $\left.\mathrm{CaO}_{2}\right) /\left(\mathrm{Cc}_{2}-\mathrm{Cu}_{2}\right)(120)$ where $\mathrm{Cc}_{2}$ is the end pulmonary capillary $\mathrm{O}_{2}$ content in $\mathrm{ml} \mathrm{O}_{2} / \mathrm{ml}$ blood calculated from the ideal alveolar $\mathrm{PO}_{2}$ (101), $\mathrm{C} \overline{\mathrm{V}} \mathrm{O}_{2}$ is the mixed-venous $\mathrm{O}_{2}$ content assumed to be 0.02 or $0.03 \mathrm{ml} \mathrm{O}_{2} / \mathrm{ml}$ blood less than arterial content (122). Invasive measurements of pulmonary blood flow include cardiac catheterization and injection of radioisotopes. During cardiac catheterization, pulmonary blood flow is calculated using the Fick principle by the measurement of $\mathrm{O}_{2}$ consumption and the arterial-venous $\mathrm{O}_{2}$ difference. Radioisotope studies involve the injection of ${ }^{133} \mathrm{Xe},{ }^{13} \mathrm{~N}$, or ${ }^{99} \mathrm{Te}$-labeled albu$\min (76)$.

The alveolar-arterial $\mathrm{PO}_{2}$ difference represents the right-to-left shunt caused by diffusion impairment, low ventilation/perfusion ratio, and anatomic shunt (117). Theoretically, true anatomic shunt is measured during breathing of $100 \% \mathrm{O}_{2}$ which overcomes both the diffusion barrier and mismatching of ventilation and perfusion. However, resorption atelectasis may occur creating a greater right-to-left shunt. The arterial-alveolar $\mathrm{PN}_{2}$ difference reflects only areas of low ventilation/perfusion ratio and the arterial-alveolar $\mathrm{CO}_{2}$ difference reflects areas of high ventilation/ perfusion ratio (alveolar dead space).

The ratio of alveolar ventilation to pulmonary blood flow is calculated by measurement of both or with the equation: $\dot{V}_{A} /$ $\dot{\mathrm{Q} p c}=\mathrm{K}\left(\mathrm{CCO}_{2}-\mathrm{C} \overline{\mathrm{V}} \mathrm{O}_{2}\right) /\left(\mathrm{P}_{\mathrm{I}} \mathrm{O}_{2}-\mathrm{P}_{\Lambda} \mathrm{O}_{2}\right)$ where $\mathrm{P}_{\mathrm{I}} \mathrm{O}_{2}$ and $\mathrm{P}_{\Lambda} \mathrm{O}_{2}$ are inspired and alveolar $\mathrm{PO}_{2}$, respectively, and $\mathrm{K}$ is a constant which converts the units to BTPS, the fractions of gases to the partial pressures and corrects for the effect of $R Q$ on $\mathrm{P}_{\Lambda} \mathrm{O}_{2}$; if $\mathrm{RQ}=1, \mathrm{~K}=863(67,117)$. The ratio thus calculated represents an average for the whole lung, and in normal adults, is approximately 0.8 . However, even in normal lungs, there is a spectrum of ventilation/perfusion ratios; the apex is relatively overventilated and the base, relatively overperfused. This is illustrated with the $\mathrm{O}_{2}-\mathrm{CO}_{2}$ diagram (Fig. 9) (116). In sick babies, the spectrum of ventilation/perfusion ratios is certainly greater. Increased right-to-left shunt causes the arterial $\mathrm{PO}_{2}$ and $\mathrm{PCO}_{2}$ to move away from the ideal alveolar $\mathrm{PO}_{2}$ and $\mathrm{PCO}_{2}$ toward the mixed venous point and increased alveolar dead space causes the alveolar $\mathrm{PO}_{2}$ and $\mathrm{PCO}_{2}$ to move toward the inspired gas point, resulting in large alveolar-arterial differences for both $\mathrm{O}_{2}$ and $\mathrm{CO}_{2}$ (117).

Applications. These techniques have been used in babies to understand how the lung functions in health and disease. The ideal alveolar-arterial $\mathrm{PO}_{2}$ difference is the most widely used assessment of the ventilation/perfusion relationship (102, 123, 124). As this difference is affected by the inspired $\mathrm{O}_{2}$, the ratio of alveolar to arterial $\mathrm{PO}_{2}$ and the ratio of $\mathrm{F}_{1} \mathrm{O}_{2}$ to arterial $\mathrm{PO}_{2}$ have been used to compare babies when $\mathrm{F}_{1} \mathrm{O}_{2}$ varies. Adamson et al. (125) calculated anatomic shunt (in $\mathrm{O}_{2}$ ) and venous admixture (in air) in babies with respiratory distress syndrome and chronic lung disease and found decreased anatomic shunt but increased venous admixture in the latter group.

Limitations. The noninvasive technique for pulmonary capillary perfusion measures only flow through ventilated alveoli, whereas the invasive techniques measure total flow. The latter

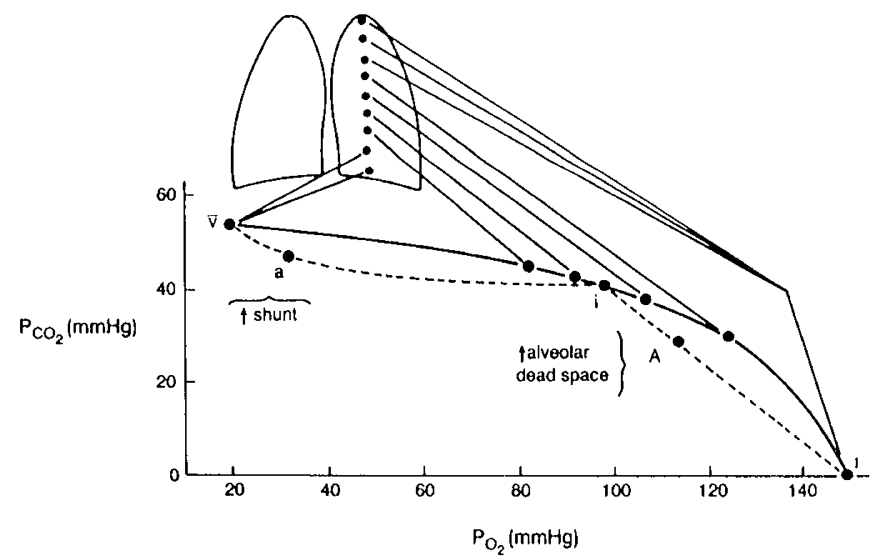

Fig. 9. The $\mathrm{O}_{2}-\mathrm{CO}_{2}$ diagram illustrating gas exchange in a lung with a poorly perfused upper zone and a poorly ventilated lower zone. Only the middle zone is contributing significantly to gas exchange. Increased shunt causes the arterial point (a) to move away from the ideal point $(i)$ along the blood RQ line toward the mixed venous point $(\bar{v})$. Increased alveolar dead space causes the alveolar point $(A)$ to move away from $\mathrm{i}$ along the gas RQ line towards the inspired point $(I)$. These result in large alveolar-artcrial differences for $\mathrm{O}_{2}$ and $\mathrm{CO}_{2}, 80$ and $20 \mathrm{~mm} \mathrm{Hg}$, respectively. [Adapted from West (117).]

techniques are only rarely used for research. Both the Berggren equation and the $\dot{V} / \dot{Q}$ equation make assumptions regarding the arterial-venous $\mathrm{O}_{2}$ difference, the affinity of fetal hemoglobin for $\mathrm{O}_{2}$, and the pulmonary capillary $\mathrm{PO}_{2}$.

\section{CONTROL OF VENTILATION}

Definition. Richards (126) described the control of breathing as a strange phenomenon "caught midway between the conscious and the unconscious, and peculiarly sensitive to both." The conscious responses are controlled by the cortex and the unconscious and vagal responses are controlled by the brain stem (Fig. 10) (127). In the newborn, control of breathing is unique because it varies with maturity, activity, noise level, oxygenation, and temperature (128).

Background. Much time and effort was devoted to discovering the cause of the onset of breathing at birth (129-131). Although in 1905, Ahlfeld (132) described breathing movements in utero, most physiologists discounted his work and unquestioningly accepted Barcroft's (129) findings of apnea in the unasphyxiated exteriorized lamb fetus. In 1960 , there were three theories about peripheral chemoreceptor function in the newborn: Girard et al. (133) believed that it was absent at birth, Miller (134) believed that it was weak, and Cross and Warner (135) believed that it was hyperactive. Both Miller (134) and Cross et al. (136) believed that central chemoreceptor function was mature in term and preterm infants. For many years, $5 \% \mathrm{CO}_{2}$ in oxygen was used for resuscitation of the newborn in the belief that $\mathrm{CO}_{2}$ would initiate breathing.

Difficulties in understanding peripheral chemoreceptor function in newborns were related to the biphasic response to low oxygen (an immediate hyperventilation followed by a depression in breathing) (136-138). Ceruti (139) found that the initial hyperventilation was abolished in a cool environment (Fig. 11). Both Cross et al. (136) and Rigatto and Brady (140) attributed the depression in breathing to a central hypoventilation since low $\mathrm{O}_{2}$ decreased the $\mathrm{CO}_{2}$ response and high $\mathrm{O}_{2}$ increased it (141). These findings, unique to term infants for the first $2 \mathrm{wk}$ of life and preterm infants for the first $4 \mathrm{wk}$, were consistent with the rediscovery of fetal breathing movements in 1977 which cease with hypoxemia and increase with hypercapnea (142). Central chemoreceptor responses were found even in very immature infants, but the slope of the $\mathrm{CO}_{2}$ response curve was 


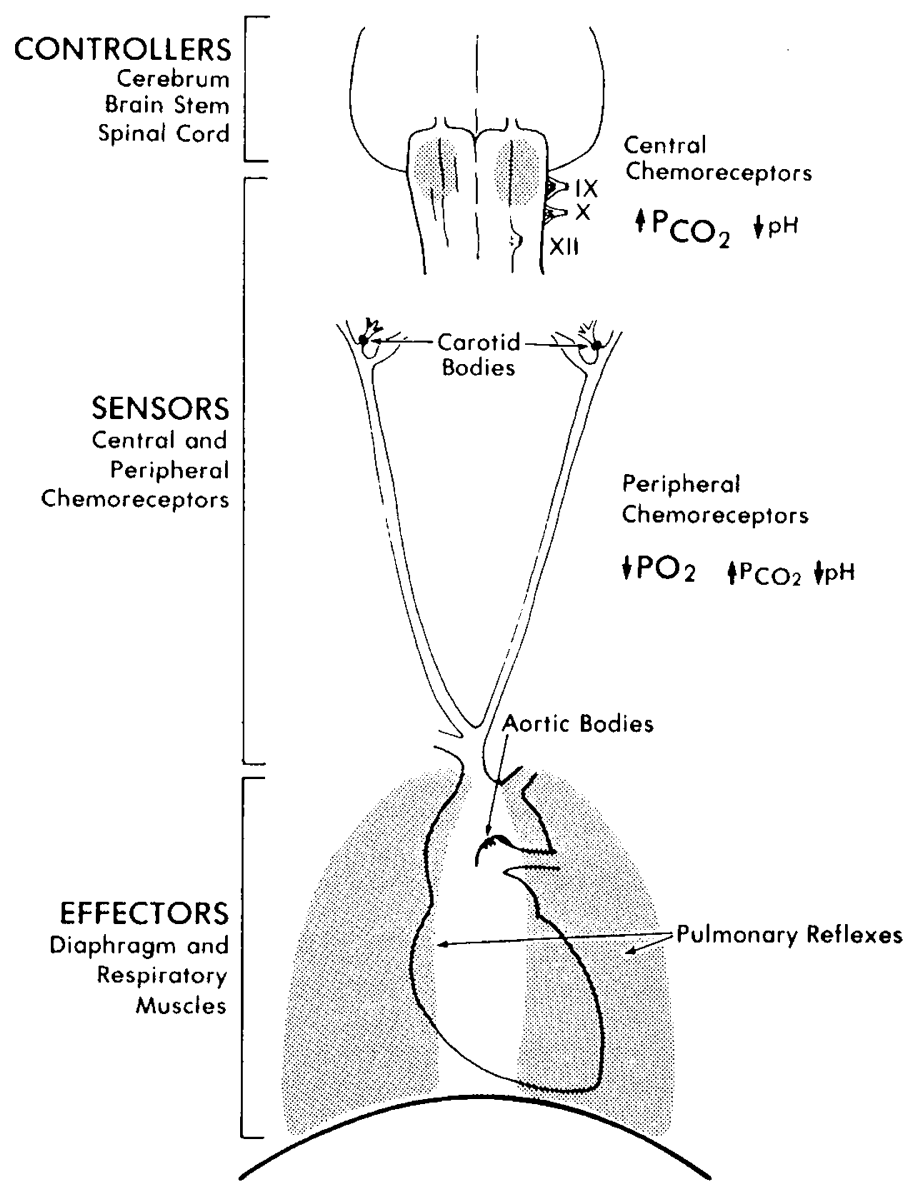

Fig. 10. Diagram of the brain centers, peripheral chemoreceptors, and effectors in man. The peripheral chemoreceptors respond to decreased $\mathrm{PO}_{2}$ and $\mathrm{pH}$ and increased $\mathrm{PCO}_{2}$ and the central chemoreceptors respond to decreased $\mathrm{PCO}_{2}$ and $\mathrm{pH}$. [Adapted from Berger et al. (127).]

shifted to the right, probably due to their unstable chest wall and FRC (143).

Technique. Chemoreceptor control is tested by measuring the changes in minute ventilation in response to a change in inspired oxygen or carbon dioxide and vagal control, by the changes in the duration of inspiratory effort during airway occlusion. Ideally, studies are performed during quiet sleep determined by an EEG (128) but often sleep state is inferred from behavior (144). The infant should be in a neutral thermal environment (139) and the concentrations of inspired and expired $\mathrm{O}_{2}$ and $\mathrm{CO}_{2}$ must be measured precisely to be sure of the stimulus. To evaluate the peripheral chemoreceptors in older infants, a 30-s challenge of high or low $\mathrm{O}_{2}$ is adequate; in younger infants, 2-3 min are required to elicit the biphasic response. To evaluate the central chemoreceptors, air and one or two levels of $\mathrm{CO}_{2}(2 \%$ and $4-5 \% \mathrm{CO}_{2}$ ) are administered for $4-6 \mathrm{~min}$ each. The change in minute ventilation in response to a change in arterial, endtidal, or skin surface $\mathrm{PCO}_{2}$ is calculated (the $\mathrm{CO}_{2}$ response curve) (145). Because of difficulties in keeping a mask or nose piece over the sleeping infant's face, we have devised a method using only a nasal catheter to measure inspired and expired $\mathrm{CO}_{2}$ and $\mathrm{O}_{2}$ (146). Other investigators have looked at arousal response, the lowest end-tidal $\mathrm{CO}_{2}$ which produces arousal from sleep during hypercapnea (147). Vagal reflexes are measured by occlusion of the airway at end-expiration (Fig. 12) (148). The duration of the subsequent inspiratory effort is compared with the unoccluded inspiratory time and percentage prolongation calculated. High values suggest active vagal reflexes and low values, absent ones. Many trials and a rapid paper speed $(100 \mathrm{~mm} / \mathrm{s})$ are essential for valid results.

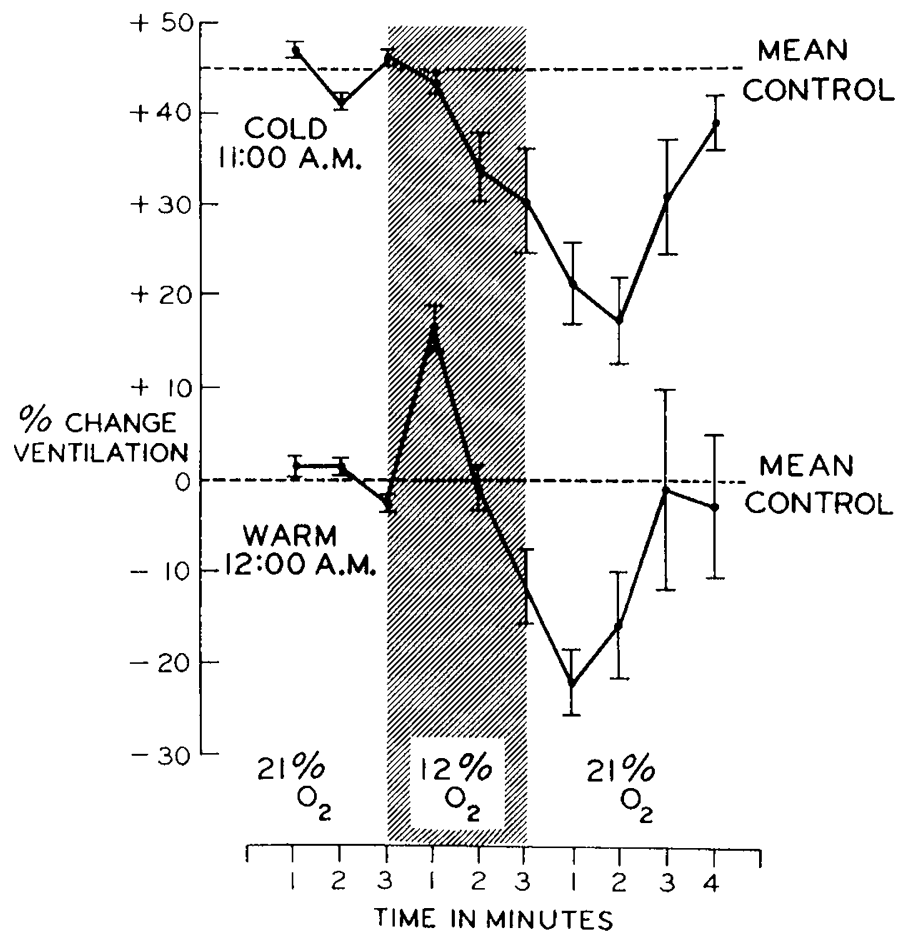

Fig. 11. Ventilatory response of the newborn to hypoxia. In a warm (neutral thermal) environment, there is a brief hyperventilation which is followed by a depression in breathing; in a cool environment, the hyperventilation is abolished. [From Ceruti (139). Reproduced by permission of Pediatrics.]

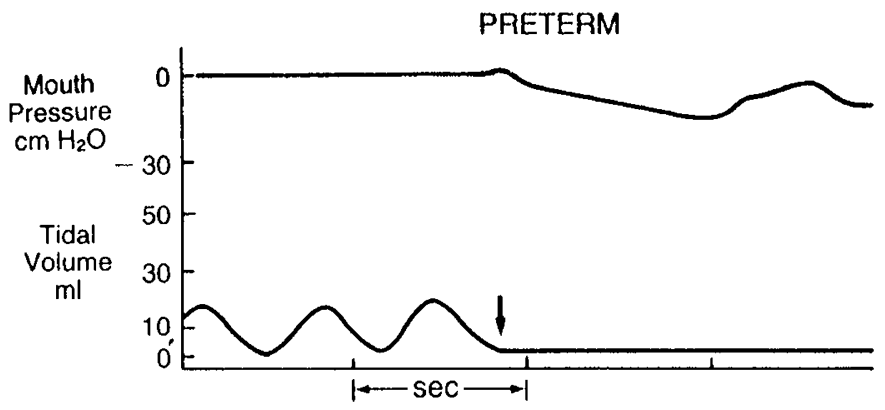

TERM

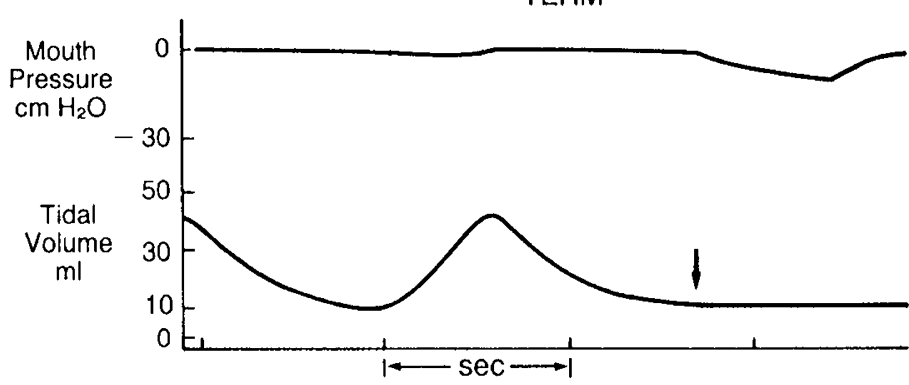

Fig. 12. Airway occlusion at end-expiration in preterm and term infants. In the preterm, occluded inspiratory effort is prolonged (1.1 versus $0.3 \mathrm{~s}$ ) suggesting an active Hering-Breuer reflex; in the term infant, it is not $(0.65$ versus $0.7 \mathrm{~s})$. [Redrawn from Olinsky et al. (148).]

Applications. There are many opinions and a plethora of studies, but no clear evidence that studies of control of ventilation are of value in detecting the infant who is at risk for prolonged apnea or sudden infant death syndrome. $\mathrm{CO}_{2}$ responses are neither very reproducible nor easy to obtain. However, preterm 
infants with recurrent apnea may have a reduced $\mathrm{CO}_{2}$ response (149) and an absent response (less than $10 \mathrm{ml} / \mathrm{kg} / \mathrm{min} /$ torr $\mathrm{PCO}_{2}$ ) is diagnostic of central hypoventilation syndrome. In all these infants, the response to therapy can be monitored by this technique.

Limitations. Adequate evaluation of the central chemoreceptors requires at least $10 \mathrm{~min}$ of quiet sleep $(5 \mathrm{~min}$ of air and 5 min of $\mathrm{CO}_{2}$ ). Values obtained before the 4 th min of hypercapnea underestimate the response. There is no consensus about the effect of chloral hydrate on the results but it is unlikely that arousal responses are valid if sedation is used.

\section{COMMENT}

Many pulmonary function techniques used in adults, even when modified for well newborns, are unsuitable for sick or small newborns. The frailty of these babies magnifies the difficulties of performing research. Clearly, however, efforts have been worthwhile; much has and is being learned about pulmonary disorders in the newborn.

Pulmonary function testing has become commonplace in adult medicine and is used routinely by the clinician. Many of the same tests are used only for research by those who care for sick newborns. Self-contained, on-line, computerized systems may make pulmonary function testing in newborns more common. It would be unfortunate, however, if these systems do not receive the same rigorous quality control that research pulmonary function laboratories follow.

Measurement of pulmonary function in babies has been developing for almost a century. We anticipate with excitement the developments of the next decade.

Acknowledgments. The authors thank Myrna Pantangco for expert manuscript preparation and Mary Helen Briscoe for illustration.

\section{REFERENCES}

1. Nelson NM 1966 Neonatal pulmonary function. Pediatr Clin North Am 3.769-799

2. Huch R, Lübbers DW, Huch A 1972 Quantitative continuous measurement of partial oxygen pressure on the skin of adults and new-born babies. Pflügers Arch 337:185-198

3. Huch R, Lübbers DW, Huch A 1974 Reliability of transcutancous monitoring of arterial $\mathrm{PO}_{2}$ in newborn infants. Arch Dis Child 49.213-218

4. Hansen TN, Tooley WH 1979 Skin surface carbon dioxide tension in sick infants. Pediatrics 64:942-945

5. Severinghaus JW, Stafford M, Bradley AF 1978 tcPCO 2 electrode design, calibration and temperature gradient problems. Acta Anaesthesiol Scand [Suppl] 68:118-122

6. Nilsson NJ 1960 Oximetry. Physiol Rev 40:1-26

7. Krauss AN, Waldman S, Frayer WW, Auld PAM 1978 Noninvasive estimation of arterial oxygenation in newborn infants. J Pediatr 93:275-278

8. Yoshiya I, Shimada Y, Tanaka K 1980 Spectrophotometric monitoring of arterial oxygen saturation in the fingertip. Med Biol Eng Comput 18:2732

9. Peabody JL, Emery JR 1985 Noninvasive monitoring of blood gases in the newborn Clin Perinatol 12:147-160

10. Versmold HT Linderkamp O. Stuffer KH, Holzmann M, Riegel KP 1978 In vivo vs. in vitro response time of transcutaneous $\mathrm{PO}_{2}$ electrodes. Acta Anaesthesiol Scand [Suppl] 68:40-48

11. Brown JT, Schur MS, McClain BC, Kafer ER 1984 In vivo response time of transcutancous oxygen measurement to changes in inspired oxygen in normal adults. Can Anacsthesiol Soc J 31:91-96

12. Severinghaus JW 1965 Blood gas concentrations. In: Fenn WO, Rahn H (eds) Handbook of Physiology Section 3: Respiration, Volume II American Physiological Socicty, Washington, DC, p 1479

13. Severinghaus JW $1981 \mathrm{~A}$ combined transcutaneous $\mathrm{PO}_{2}-\mathrm{PCO}_{2}$ clectrode with electrochemical $\mathrm{HCO}_{3}{ }^{-}$stabilization. J Appl Physiol 51:1027-1032

14. Emery JR, Peabody JL 1983 Are we misusing transcutaneous $\mathrm{PO}_{2}$ and $\mathrm{PCO}_{2}$ measurements in infants with bronchopulmonary dysplasia? Pediatr Res 17:374A(abstr)

15. Rome ES, Stork EK, Carlo WA, Martin RJ 1984 Limitations of transcutaneous $\mathrm{PO}_{2}$ and $\mathrm{PCO}_{2}$ monitoring in infants with bronchopulmonary dysplasia. Pediatrics $74: 217-220$

16. Halliday HI, Dumpit FM, Brady JP 1980 Effects of inspired oxygen on echocardiographic assessment of pulmonary vascular resistance and myocardial contractility in bronchopulmonary dysplasia. Pediatrics 65:536-540
17. Teague WG, Heldt GP, Tooley WH 1986 Hypoxia causes bronchoconstriction in infants with chronic lung disease. Pediatr Res 20:443 (abstr)

18. Whitchcad MD, Pollitzer MJ Parker D, Halsall D, Delpy DT, Rcynolds EOR 1980 Transcutaneous estimation of arterial $\mathrm{PO}_{2}$ and $\mathrm{PCO}_{2}$ in newborn infants with a single electrochemical sensor. Lancet 1:1111-1114

19. Cornclissen PJH, van Woensel CLM, van Oel WC, de Jong PA 1983 Correction factors for hemoglobin derivatives in fetal blood, as measured with the IL 282 CO-Oximeter Clin Chem 29:1555-1556

20. Jennis MS, Peabody JL 1987 Pulse oximetry--an alternative method for the assessment of oxygenation in newborn infants. Pediatrics (in press)

21. Eckerlein 1890 Zur Kenntniss des Athmungsmechanismus der Neugeborenen. Z Geburtshife Gynäkol 19:120-173

22. Murphy DP, Thorpe ES Jr 1931 Breathing measurements on normal infants J Clin Invest 10:545-558

23. Shaw LA, Hopkins FR 1931 The respiration of premature infants. Am J Dis Child 42:335-341

24. Cross KW 1949 The respiratory rate and ventilation in the newborn baby. $J$ Physiol (Lond) 109:459-474

25. Miller HC, Smull NW 1955 Further studies on the effects of hypoxia on the respiration of newborn infants. Pediatrics 16:93-103

26. Gilbert RJ, Auchincloss JH Jr, Brodsky J, Boden W 1972 Changes in tida volume, frequency and ventilation induced by their measurement. J Appl Physiol 33:252-254

27. Fleming PJ, Levine MR, Goncalves A 1982 Changes in respiratory pattern resulting from the use of a face mask to record respiration in newborn infants. Pediatr Res 16:1031-1034

28. Goldensohn ES, Zablow I. 1959 An electrical impedance spirometer. J App Physiol 14:463-464

29. Geddes LA, Hoff HE, Hickman DM, Moore $\Lambda \mathrm{G} 1962$ The impedance pneumograph. Aerospace Med 33:28-33

30. Polgar G 1965 Comparison of methods for recording respiration in newborn infants. Pediatrics 36:861-868

31. Milner AD 1970 The respiratory jacket; a new method for measuring respiration. Lancet 2:80-81

32. Duffty P, Spriet L, Bryan MH, Bryan AC 1981 Respiratory induction pleth ysmography (Respitrace ${ }^{6 y}$ ): an evaluation of its use in the infant. Am Rev Respir Dis 123:542-546

33. Lipton EL, Steinschncider A. Richmond JB 1964 Autonomic function in the neonate. VIII. Cardio-pulmonary observations. Pediatrics 33:212-215

34. Dolfin T, Duffty P, Wilkes DL, Bryan MH 1982 Calibration of respiratory induction plethysmography (Respitrace ${ }^{\circledR}$ ) in infants. Am Rev Respir Dis $126.577-579$

35. Knill R, Andrews W, Bryan AC, Bryan MH 1976 Respiratory load compenSation in infants. J $\wedge$ ppl Physiol 40:357-361

36. Drorbaugh JE, Fenn WO 1955 A barometric method for measuring ventilation in newborn infants. Pediatrics 16:81-87

37. Comroe JH Jr, Kraffert NH 1950 Measurement of gas volumes. In: Comroc JH Jr (ed) Methods in Medical Research. Ycar Book Medical Publishers, Inc. Chicago, pp 94-103

38. Lilly JC 1950 Flow meter for recording respiratory flow of human subjects. In: Comroe JH Jr (ed) Methods in Medical Research. Year Book Medical Publishers, Inc., Chicago. pp 113-121

39. Brady JP, Deming DD, MCCann EM 1985 Neonatal endotracheal flowmeter for tidal volume, airway pressure, and end-tidal gas. J Appl Physiol 58:1023-1025

40. Goldman SL, Brady JP, Dumpit FM 1979 Increased work of breathing associated with nasal prongs. Pediatrics $64: 160-164$

41. Honma Y, Wilkes D, Bryan MH, Bryan AC 1984 Rib cage and abdominal contributions to ventilatory response to $\mathrm{CO}_{2}$ in infants. 3 Appl Physiol $56: 1211-1216$

42. Warburton D, Stark AR. Tacusch HW 1977 Apnea monitor failure in infants with upper airway obstruction. Pediatrics 60:742-744

43. Berglund $G$, Karlberg P 1956 Determination of the functional residua capacity in newborn infants: preliminary report. Acta Paediatr 45.541-544

44. Strang LB, McGrath MW 1962 Alveolar ventilation in normal newborn infants studied by air wash-in after oxygen breathing. Clin Sci 23:129-139

45. Klaus M. Tooley WHI Weaver KH. Clements JA 1962 Lung volume in the newborn infant. Pediatrics 30:111-116

46. Auld PAM. Nelson NM. Cherry RB, Rudolph AJ, Smith CA 1963 Mcasurement of thoracic gas volume in the newborn infant. J Clin Invest 42:476483

47. Nelson NM. Prod'hom LS, Cherry RB, Lipsitz. PJ, Smith CA 1963 Pulmonary function in the newborn infant. V. Trapped gas in the normal infant's lung. J Clin Invest 42:1850-1857

48. Mortola JP. Fisher JT, Smith B, Fox G, Weeks S 1982 Dynamics of breathing in infants. $J$ Appl Physiol 52:1209-1215

49. LeSoucf PN, England SJ. Bryan AC 1984 Passive respiratory mechanics in newborns and children. Am Rev Respir Dis 129:552-556

50. Krauss $\triangle N$, Auld PAM 1970 Measurement of functional residual capacity in distressed neonates by helium rebreathing. J Pediatr 77:228-232

51. Geubelle PF, Karlberg P, Koch G, Lind J, Wallgren G, Wegelius C 1959 L'aćration du poumon chez le nouveau-né. Biol Neonatorum 1:169-210

52. Chu J. Clements JA, Cotton EK, Klaus MH, Sweet AY, Tooley WH 1967 Neonatal pulmonary ischemia. Part I: Clinical and physiological studies Pediatrics 40:709-782

53. Gerhardt T, Hehre D, Bancalari E, Watson H 1985 A simple method for measuring functional residual capacity by $\mathrm{N}_{2}$ washout in small animals and newborn infants. Pediatr Res 19:1165-1169 
54. Richardson P, Wyman M, Jung AL 1980 A method of estimating the functional residual capacity of infants with respiratory distress syndrome. Crit Care Med 8:667-670

55. Richardson CP, Jung AL 1978 Effects of continuous positive airway pressure on pulmonary function and blood gases of infants with respiratory distress syndrome. Pediatr Res 12:771-774

56. Richardson P, Anderson M 1982 Automated nitrogen-washout methods for infants: evaluated using cats and a mechanical lung. J Appl Physiol $52: 1378-1382$

57. Ozanne GM, Zinn SE, Fairley HB 1981 Measurement of functional residual capacity during mechanical ventilation by simultaneous exchange of two insoluble gases. Anesthesiology 54:413-417

58. Bose CL, Lawson EE, Greene A, Mentz W, Friedman M 1986 Measurement of cardiopulmonary function in ventilated neonates with respiratory distress syndrome using rebreathing methodology. Pediatr Res 20:316-320

59. Kao LC, Warburton D, Sargent CW, Platzker ACG, Keens TG 1983 Furosemide acutely decreases airways resistance in chronic bronchopulmonary dysplasia. J Pediatr 103:624-629

60. Kao LC, Warburton D, Cheng MH, Cedeño C, Platzker ACG, Keens TG 1984 Effect of oral diuretics on pulmonary mechanics in infants with chronic bronchopulmonary dysplasia: results of a double-blind crossover sequential trial. Pediatrics 74:37-44

61. Fox WW, Schwartz JG, Shaffer TH 1979 Effects of endotracheal tube leaks on functional residual capacity detcrmination in intubated neonates. Pediatr Res 13:60-64

62. Dantzker DR, Wagner PD, West JB 1975 Instability of lung units with low $\dot{\mathrm{V}}_{\wedge} / \dot{Q}$ ratios during $\mathrm{O}_{2}$ breathing. J Appl Physiol 38:886-895

63. Wolfson MR, Bhutani VK, Shaffer TH, Bowen FW Jr 1984 Mechanics and energetics of breathing helium in infants with bronchopulmonary dysplasia. J Pediatr 104:752-757

64. Butt WW, Koren G, England S, Shear NH, Whyte H, Bryan CA, Swyer PR 1985 Hypoxia associated with helium-oxygen therapy in neonates. J Pediatr 106:474-477

65. Godfrey S, Beardsmore CS, Maayan C, Bar-Yishay E 1986 Can thoracic gas volume be measured in infants with airways obstruction? Am Rev Respir Dis 133:245-251

66. Geubelle F, Senterre J 1969 Methods of investigation of the mechanics of breathing in the artificially ventilated newborn. Biol Neonate 16:35-46

67. Comroe JH Jr, Forster RE II, DuBois AB, Briscoe WA, Carlsen E 1962 The Lung: Clinical Physiology and Pulmonary Function Tests. Year Book Medical Publishers, Inc., Chicago

68. Karlberg P, Cook CD, O'Brien D, Cherry RB, Smith CA 1954 Studies of respiratory physiology in the newborn infant. II. Observations during and after respiratory distress. Acta Paediatr 43(suppl 100):397-411

69. McIlroy MB, Tomlinson ES 1955 The mechanics of breathing in newly born babies. Thorax 10:58-61

70. Cook CD, Sutherland JM, Segal S, Cherry RB, Mcad J, McIlroy MB, Smith CA 1957 Studies of respiratory physiology in the newborn infant. III. Measurements of mechanics of respiration. J Clin Invest 36:440-448

71. Swyer PR, Reiman RC, Wright JJ 1960 Ventilation and ventilatory mechanics in the newborn J Pediatr 56:612-622

72. Senterre J, Geubelle F 1970 Measurement of endocsophageal pressure in the newborns. Biol Neonate 16:47-53

73. Lemen R, Benson M, Jones JG 1974 Absolute pressure measurements with hand-dipped and manufactured esophageal balloons. J Appl Physiol 37:600-603

74. Asher MI, Coates AL, Collinge JM, Milic-Emili J 1982 Measurement of pleural pressure in neonates. J Appl Physiol 52:491-494

75. Beardsmore CS. Helms P, Stocks J, Hatch DJ, Silverman M 1980 Improved esophageal balloon technique for use in infants. J Appl Physiol 49:735-742

76. Bancalari E 1986 Pulmonary function testing and other diagnostic laboratory procedures. In: Thibeault DW, Gregory GA (cds) Neonatal Pulmonary Care. Appleton-Century-Crofts, Norwalk, CT, pp 195-233

77. Tepper RS, Pagtakhan RD, Taussig LM 1984 Noninvasive determination of total respiratory system compliance in infants by the weighted-spirometer method. Am Rev Respir Dis 130:461-466

78. Teague WG Jr, Darnall RA, Suratt PM 1985 A noninvasive constant-flow method for measuring respiratory compliance in newborn infants. Crit Care Med 13:965-97!

79. Rossi A, Gottfried SB, Zocchi L, Higgs BD, Lennox S, Calverley PMA, Begin P. Grassino A. Milic-Emili J 1985 Measurement of static compliance of the total respiratory system in patients with acute respiratory failure during mechanical ventilation. Am Rev Respir Dis 131:672-677

80. Thomson A, Silverman M 1985 Single-breath measurement of lung mechanics in very low birth weight infants. Crit Care Med 13:4-8

81. Kricger I 1963 Studies on mechanics of respiration in infancy. Am J Dis Child 105:439-448

82. Tapia JL, Gerhardt T, Goldman SL, Hehre D, Bancalari E 1982 Influence of tidal volume on lung compliance and resistance in infants with acute respiratory failure. Clin Res 30:908(abstr)

83. Polgar G 1961 Airway resistance in the newborn infant: preliminary report. J Pediatr 59:915-921

84. DuBois $\wedge$ B, Botelho SY, Comroe JH Jr 1956 A new method for measuring airway resistance in man using a body plethysmograph: values in normal subjects and in patients with respiratory disease. J Clin Invest 35:327-335

85. Stocks J, Levy NM, Godfrey S 1977 A new apparatus for the accurate measurement of airway resistance in infancy. J Appl Physiol 43:155-159
86. Goldman SL, Gerhardt T, Sonni R, Feller R, Hehre D, Tapia JL, Bancalari E 1983 Early prediction of chronic lung disease by pulmonary function testing. J Pediatr 102:613-617

87. McCann EM, Lewis K, Deming DD, Donovan MJ, Brady JP 1985 Controlled trial of furosemide therapy in infants with chronic lung disease. $J$ Pediatr 106:957-962

88. Lloyd BW, McCann EM, Goldman SL, Lewis KW 1986 Lengthening inspiratory time improves oxygenation, tidal volume and compliance in infants with bronchopulmonary dysplasia. Pediatr Res 20:434A(abstr)

89. Godfrey S, Bar-Yishay E, Arad I, Landau LI, Taussig LM 1983 Flow-volume curves in infants with lung disease. Pediatrics 72:517-522

90. Ahlström H 1974 Studies on pulmonary mechanics in infants. Acta Paediatr Scand (Suppl) 244:1-21

91. LeSouëf PN, Lopes JM, England SJ, Bryan MH, Bryan AC 1983 Influence of chest wall distortion on esophageal pressure. J Appl Physiol 55:353-358

92. Beardsmore CS, Stocks J, Silverman M 1983 Esophageal pressure in infants at elevated lung volumes and positive airway pressure. J Appl Physiol 55:377-382

93. Rodenstein DO, Stănescu DC, Francis C 1982 Demonstration of failure of body plethysmography in airway obstruction. J Appl Physiol 52:949-954

94. Beardsmore CS, Stocks J, Silverman M 1982 Problems in measurement of thoracic gas volume in infancy. J Appl Physiol 52:995-999

95. Helms P 1982 Problems with plethysmographic estimation of lung volume in infants and young children. J Appl Physiol 53:698-702

96. Stocks J, Godfrey S 1977 Specific airway conductance in relation to postconceptional age during infancy. J Appl Physiol 43:144-154

97. Wanner A, Zarzecki S, Atkins N, Zapata A, Sackner MA 1974 Relationship between frequency dependence of lung compliance and distribution of ventilation. J Clin Invest 54:1200-1213

98. Nelson NM, Prod'hom LS, Cherry RB, Lipsitz PJ, Smith CA 1962 Pulmonary function in the newborn infant. I. Methods: ventilation and gaseous metabolism. Pediatrics 30:963-974

99. Strang LB 1961 Alveolar gas and anatomical dead-space measurements in normal newborn infants. Clin Sci 21:107-114

100. Brady JP, Ariagno RL, Watts JL, Goldman SL, Dumpit FM 1978 Apnea, hypoxemia, and aborted sudden infant death syndrome. Pediatrics 62:686691

101. Riley RL, Cournand A 1949 'Ideal' alveolar air and the analysis of ventilationperfusion relationships in the lungs. $\mathrm{J}$ Appl Physiol 1:825-847

102. Nelson NM, Prod'hom LS, Cherry RB, Lipsitz PJ, Smith CA 1963 Pulmonary function in the newborn infant: the alveolar-arterial oxygen gradient. $\mathbf{J}$ Appl Physiol 18:534-538

103. Corbet AJS, Ross JA, Beaudry PH, Stern L 1974 Ventilation-perfusion relationships as assessed by $\mathrm{aADN}_{2}$ in hyaline membrane disease. $\mathrm{J}$ Appl Physiol 36:74-81

104. Fowler WS 1948 Lung function studies. II. The respiratory dead space. Am J Physiol 154:405-416

105. Nelson NM, Prod'hom LS, Cherry RB, Lipsitz PJ, Smith CA 1962 Pulmonary function in the newborn infant. II. Perfusion-estimation by analysis of the arterial-alveolar carbon dioxide difference. Pediatrics 30:975-989

106. Dumpit FM, Brady JP 1978 A simple technique for measuring alveolar $\mathrm{CO}_{2}$ in infants. J Appl Physiol 45:648-650

107. Stahlman MT 1957 Pulmonary ventilation and diffusion in the human newborn infant. J Clin Invest 36:1081-1091

108. Fowler WS, Cornish ER Jr, Kety SS 1952 Lung function studies. VIII. Analysis of alveolar ventilation by pulmonary $N_{2}$ clearance curves. $J$ Clin Invest 31:40-50

109. Godfrey S, McKenzie S 1977 The place of radioisotopic lung function studies in paediatrics. Arch Dis Child 52:859-864

110. Heaf DP, Helms P, Gordon 1, Turner HM 1983 Postural effects on gas exchange in infants. N Engl J Med 308:1505-1508

111. Hanson JS, Shinozaki T 1970 Hybrid computer studies of ventilatory distribution and lung volume. I. Normal newborn infants. Pediatrics 46:900914

112. Hutchison AA, Sum AC, Demis TA, Erben A, Landau LI 1982 Moment analysis of multiple breath nitrogen washout in children. Am Rev Respir Dis 125:28-32

113. Briscoe WA, Cournand A 1959 Uneven ventilation of normal and diseased lungs studied by an open-circuit method. J Appl Physiol 14:284-290

114. Weygandt GR 1976 A sensitive five-breath $\mathrm{N}_{2}$ washout test of distribution of ventilation. J Appl Physiol 40:464-467

115. Watts JL, Ariagno RL, Brady JP 1977 Chronic pulmonary disease in neonates after artificial ventilation: distribution of ventilation and pulmonary interstitial emphysema. Pediatrics 60:273-281

116. Rahn H, Fenn WO 1955 A Graphical Analysis of the Respiratory Gas Exchange: The $\mathrm{O}_{2}-\mathrm{CO}_{2}$ Diagram. The American Physiological Society, Washington, DC, pp 13-18

117. West JB 1977 Ventilation/Blood Flow and Gas Exchange. Blackwell Scientific Publications, Oxford, pp 53-106

118. Brady JP, Rigatto H 1971 Pulmonary capillary flow in the newborn infant: a new method using the plethysmograph and nitrous oxide. Pediatrics 48:207-215

119. Orme R L'E, Featherby EA, Rigatto H, Cervantes FJ, Brady JP 1973 Effective pulmonary blood flow in preterm infants with and without respiratory distress: a simple bedside method using nitrous oxide. Pediatrics 52:179187

120. Berggren SM 1942 The oxygen deficit of arterial blood caused by non- 
ventilating parts of the lung. Acta Physiol Scand 4(suppl 11):1-92

121. Ledbetter MK, Homma T, Farhi LE 1967 Readjustment in distribution of alveolar ventilation and lung perfusion in the newborn. Pediatrics 40:940945

122. Rudolph AM, Drorbaugh JE, Auld PAM, Rudolph AJ, Nadas AS, Smith CA, Hubbell JP 1961 Studies on the circulation in the neonatal period: the circulation in the respiratory distress syndrome. Pediatrics 27:551-566

123. Murdock AI, Swyer PR 1968 The contribution to venous admixture by shunting through the ductus arteriosus in infants with the respiratory distress syndrome of the newborn. Biol Neonatorum 13:194-210

124. Mammel MC, Green TP, Johnson DE, Thompson TR 1983 Controlled trial of dexamethasone therapy in infants with bronchopulmonary dysplasia. Lancet 1:1356-1358

125. Adamson TM, Hawker JM, Reynolds EOR, Shaw JL 1969 Hypoxemia during recovery from severe hyaline membrane disease. Pediatrics 44:168-178

126. Richards DW Jr 1953 The nature of cardiac and of pulmonary dyspnea. Circulation 7:15-29

127. Berger AJ, Mitchell RA, Severinghaus JW 1977 Regulation of respiration. N Engl J Med 297:92-97

128. Bryan AC, Bryan MH 1978 Control of respiration in the newborn. Clin Perinatol 5:269-281

129. Barcroft J 1946 The onset of respiratory movement. In: Researches on PreNatal Life. Blackwell Scientific Publications, Oxford, pp 260-272

130. Weisbrot IM, James LS, Prince CE, Holaday DA, Apgar V 1958 Acid-base homeostasis of the newborn infant during the first 24 hours of life. J Pediatr $52: 395-403$

131. Harned HS Jr, Griffin CA III, Berryhill WS Jr, MacKinney LG, Sugioka K 1967 Role of carotid chemoreceptors in the initiation of effective breathing of the lamb at term. Pediatrics 39:329-336

132. Ahlfeld F 1905 Die intrauterine Tätigkeit der Thorax- und Zwerch-fellmuskulatur. Intrauterine Atmung. Monatsschr Geburtshäfe Gynükol 21:143163

133. Girard F, Lacaisse A, Dejours $\mathrm{P} 1960$ Le stimulus $\mathrm{O}_{2}$ ventilatoire à la période néonatale chez l'homme. J Physiol (Paris) 52:108-109

134. Miller HC 1954 Effect of high concentrations of carbon dioxide and oxygen on the respiration of fullterm infants. Pediatrics 14:104-113

135. Cross KW, Warner P 195! The effect of inhalation of high and low oxygen concentrations on the respiration of the newborn infant. J Physiol (Lond) 114:283-295

136. Cross KW, Hooper JMD, Lord JM 1954 Anoxic depression of the medulla in the new-born infant. $J$ Physiol (Lond) 125:628-640

137. Brady JP, Ceruti E 1966 Chemoreceptor reflexes in the new-born infant: effects of varying degrees of hypoxia on heart rate and ventilation in a warm environment. J Physiol (Lond) 184:631-645

138. Rigatto H, Brady JP, Verduzco $R$ de la $T 1975$ Chemoreceptor reflexes in preterm infants: $I$. The effect of gestational and postnatal age on the ventilatory response to inhalation of $100 \%$ and $15 \%$ oxygen. Pediatrics 55:604-613

139. Ceruti E 1966 Chemoreceptor reflexes in the newborn infant: effect of cooling on the response to hypoxia. Pediatrics 37:556-564

140. Rigatto H, Brady JP 1972 Periodic breathing and apnea in preterm infants. I. Evidence for hypoventilation possibly due to central respiratory depression. Pediatrics 50:202-218

141. Rigatto H, Verduzco R de la T, Cates DB 1975 Effects of $\mathrm{O}_{2}$ on the ventilatory response to $\mathrm{CO}_{2}$ in preterm infants. J Appl Physiol 39:896-899

142. Boddy K, Dawes GS 1975 Fetal breathing. Br Med Bull 31:3-7

143. Rigatto $H$, Brady JP, Verduzco $R$ de la $T 1975$ Chemoreceptor reflexes in preterm infants. II. The effect of gestational and postnatal age on the ventilatory response to inhaled carbon dioxide. Pediatrics 55:614-620

144. Dittrichová J 1966 Development of sleep in infancy. J Appl Physiol 21:12431246

145. Avery ME, Chernick V, Dutton RE, Permutt S 1963 Ventilatory response to inspired carbon dioxide in infants and adults. J Appl Physiol 18:895-903

146. Brady JP, Durand M, McCann E 1983 A simple method for estimating the ventilatory response to $\mathrm{CO}_{2}$ in infants. Am Rev Respir Dis 127:422-424

147. McCulloch K, Brouillette RT, Guzzetta AJ, Hunt CE 1982 Arousal responses in near-miss sudden infant death syndrome and in normal infants. J Pediatr 101:911-917

148. Olinsky A, Bryan MH, Bryan AC 1974 Influence of lung inflation on respiratory control in neonates. J Appl Physiol 36:426-429

149. Gerhardt T, Bancalari E 1984 Apnea of prematurity: I. Lung function and regulation of breathing. Pediatrics 74:58-62

150. Hjalmarson O 1974 Mechanics of breathing in newborn infants with pulmonary disease. Acta Paediatr Scand (Suppl) 247:1-70 